\title{
PRELIMINARY APPRAISAL OF THE HYDROLOGY OF THE STIGLER AREA, HASKELL COUNTY, OKLAHOMA
}

By Melvin V. Marcher, Thomas L. Huntzinger, Jerry D. Stoner, and Stephen P. Blumer

U.S. GEOLOGICAL SURVEY

WATER-RESOURCES INVESTIGATIONS 82-4099

Prepared in cooperation with the U.S. BUREAU OF LAND MANAGEMENT under the Energy Minerals Rehabilitation Inventory and Analysis Program

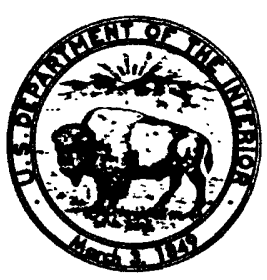




\title{
UNITED STATES DEPARTMENT OF THE INTERIOR JAMES G. WATT, Secretary
}

\author{
GEOLOGICAL SURVEY
}

Dallas L. Peck, Director

For additional information write to:

James H. Irwin, District Chief

U.S. Geological Survey

Water Resources Division

Rm. 621, Dld Post Office Bldg.

215 Dean A. Mc Gee Avenue

Oklahoma City, Ok 73102

Telephone : 405-231-4256
Copies of this report can be purchased from:

Open-File Services Section

Western Distribution Branch

U.S. Geological Survey

Box 25425, Federal Center

Lakewood, Colorado 80225

(Telephone: (303) 234-5888) 


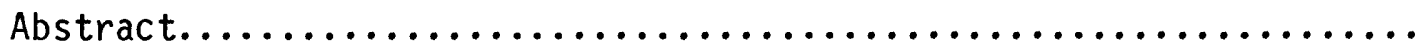

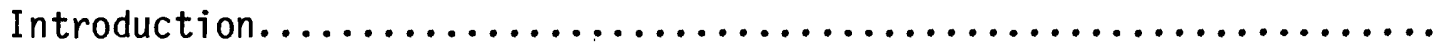

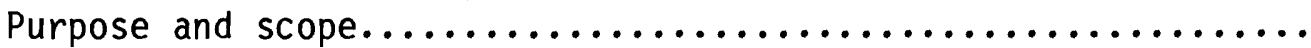

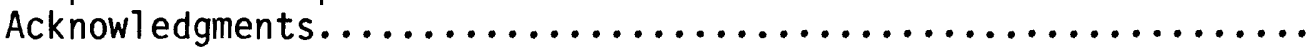

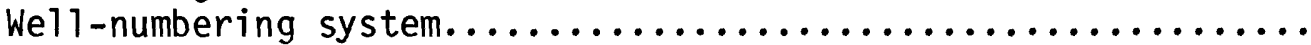

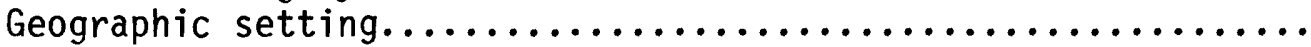

Climate........................................

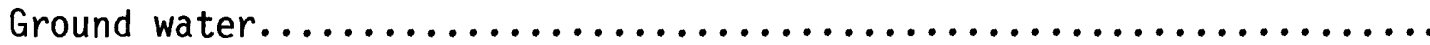

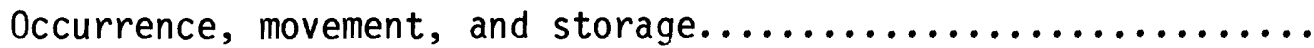

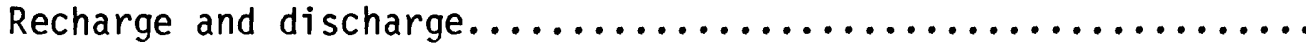

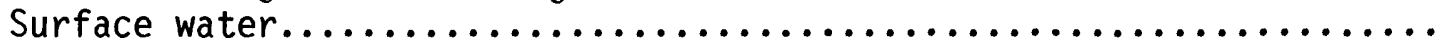

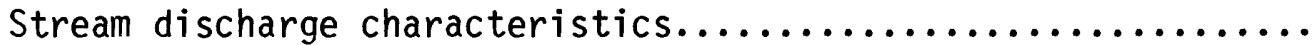

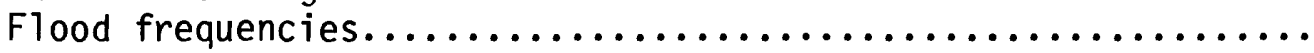

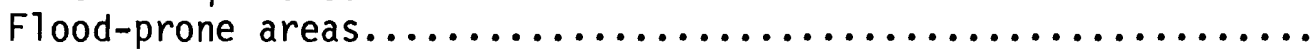

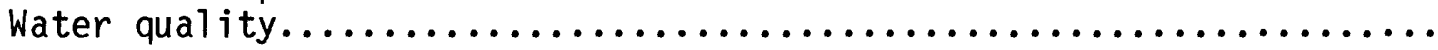

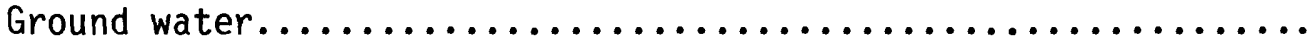

Surface water...................................

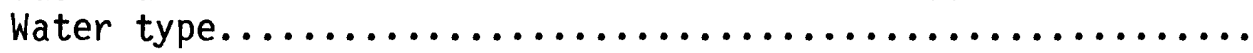

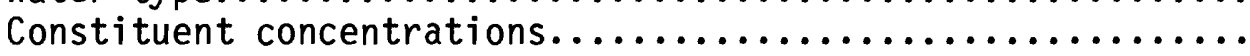

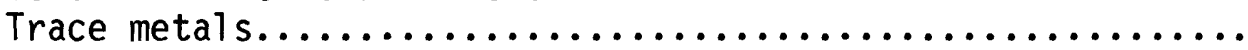

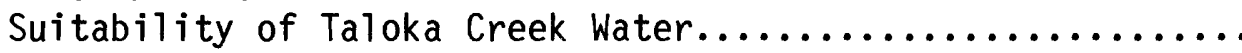

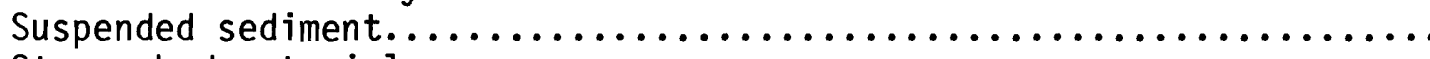

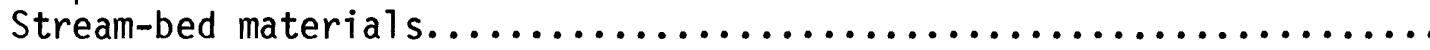

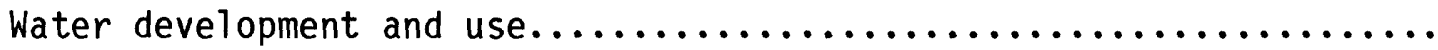

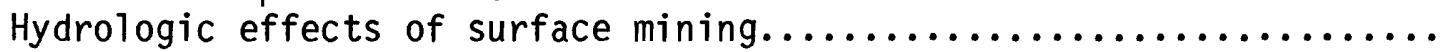

Summary..........................................

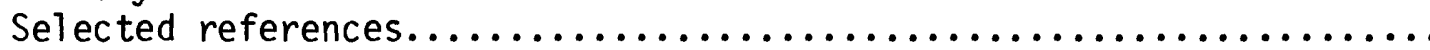

\section{ILLUSTRATIONS}

\section{(P1ates are in pocket)}

Plate 1. Geologic map of the Stigler area, Haskell County, Oklahoma.

2. Potentiometric map showing location of the data collection sites and rural water-district water lines in the Stigler area, Haskel1 County, Oklahoma.

3. Map showing flood-prone areas in the Stigler area, Haskell County, Oklahoma.

Figure 1. Map showing location of the Stigler area.............

2. Trilinear diagram of average concentrations of common constituents in surface water in the Stigler area.........

3. Graphs showing relationship between stream discharge and

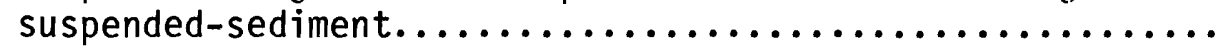

4. Schematic cross sections showing stages of surface mining

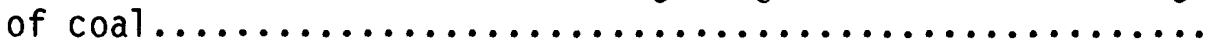




\section{CONTENTS (continued)}

Table 1. Records of wells and selected ground-water quality data........................................ 6

2. Discharge of Taloka Creek near Stigler

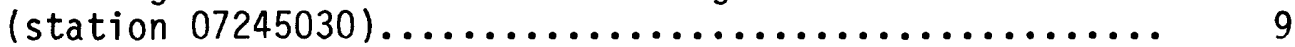

3. Discharge of Taloka Creek tributary

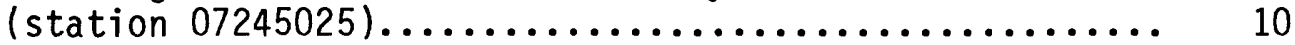

4. Discharge of Taloka Creek at Stigler (station 07245020)................................ 11

5-7. Mean, minimum, and maximum values for selected physical properties and chemical constituents of water from:

5. Taloka Creek near Stigler (station 07245030)........ 16

6. Taloka Creek tributary (station 07245025)........... 17

7. Taloka Creek at Stigler (station 07245020).......... 18

8-9. Selected physical properties and chemical constituents of water from:

8. Taloka Creek near Stigler (station 07245030)........ 19

9. Taloka Creek at Stigler (station 07245020)......... 20

10. Comparison of selected physical properties and chemical constituents of water from Taloka Creek at Stigler (station 07245020) and Taloka Creek near Stigler (station 07245030)............................. 21

11-13. Suspended sediment data for: 11. Tal oka Creek near Stigler (station 07245030)....... 26 12. Tal oka Creek tributary (station 07245025)......... 27 13. Taloka Creek at Stigler (station 07245020)........ 28

14. Summary of suspended-sediment data.................. 29

15. Selected trace constituents and nutrients in stream-bed material...................................... 


\section{PRELIMINARY APPRAISAL OF THE HYDROLOGY OF THE}

STIGLER AREA, HASKELL COUNTY, OKLAHOMA

by

Melvin V. Marcher, Thomas L. Huntzinger,

Jerry D. Stoner, and Stephen P. Blumer

\section{ABSTRACT}

Bedrock in the Stigler area of southeastern Oklahoma consists principally of shale, siltstone, and sandstone of the McAlester, Savanna, and Boggy Formations of Pennsylvanian age. These rocks have been folded to form the Stigler syncline on the north and the Antioch anticline on the south. An area of several square miles is underlain by terrace deposits, mostly sandy silt, as much as 25 feet thick. Alluvium along the streams is 5 to 10 feet thick and consists mainly of sandy silt. Neither the terrace deposits nor the alluvium are hydrologically significant.

Water in the bedrock is under artesian conditions. Well depths range from 34 to 235 feet and average 95 feet. The water level in most wells is less than 30 feet below the land surface. Because the rocks have minimal permeability, well yields probably are less than 5 gallons per minute. Much of the area is provided with water by a rural water district. Based on specific-conductance measurements, dissolved-solids concentrations in ground water are estimated to range from 200 to 2,500 milligrams per liter. No relationship between variations in specific conductance and well depth, geographic distribution, or geologic formation is apparent.

Streams in the area are ephemeral and extended periods of no flow can be expected. During much of the period of record, streamflow in Taloka Creek was maintained by water pumped from an active coal mine. Water upstream from the mine area had a mean dissolved-solids concentration of 72 milligrams per liter whereas water downstream from the mine area had a mean concentration of 1,323 milligrams per liter. At times, downstream concentrations of some toxic metals exceeded the standards for drinking water set by the U.S. Environmental Protection Agency. Samples of water collected from Taloka Creek since mining ceased did not have excessive concentrations of toxic metals. Maximum suspended-sediment discharge of Taloka Creek was about 1,660 tons per day. Silt-clay particles (diameters less than 0.062 millimeter) were the dominant grain size.

Observed or measured effects of surface mining for coal on the hydrologic system include (1) creation of additional water storage in the surface mine pond, (2) disruption of drainage in an area of about 1 square mile, and (3) increased mineralization of water in Taloka Creek. Other possible effects include (4) changes in permeability and storage of water in mine spoil, (5) minor changes in streamflow and runoff characteristics, and (6) temporary increase in the sediment load of Taloka Creek. 


\section{Purpose and Scope}

The U.S. Bureau of Land Management is charged with assessing the probable water-resources impacts on any area under Federal jurisdiction where coal might be mined by surface methods. To meet this responsibility, the EMRIA (Energy Minerals Rehabilitation Inventory and Analysis) program was developed. As part of this program, the U.S. Geological Survey was requested to collect and analyze hydrologic data for selected areas in eastern 0klahoma that have potential for surface mining of coal. One such area includes the basins of Taloka and Jackson Creeks near Stigler in north-central Haskell County (fig. 1). In this area, the Stigler coal is at or near the surface and thus amenable to surface mining.

The purpose of this report is to describe the hydrology of the Stigler area, based on the limited data collected since October, 1978. These data include: (1) Continuous discharge and periodic samples for chemical quality and sediment at a downstream site on Taloka Creek (station 07245030), (2) periodic discharge and samples for chemical quality and sediment at an upstream site on Taloka Creek (station 07245020), (3) periodic discharge and samples for chemical quality and sediment from a tributary of Taloka Creek (station 07245025), (4) records of 34 wells including onsite determination of specific conductance and $\mathrm{pH}$ of water from 28 wells, and (5) laboratory determinations of dissolved chloride, sulfate, iron, manganese in water from 10 wells.

Information on the geology of the area, as related to hydrology, is taken from a report by Oakes and Knechtel (1948) supplemented with onsite observations, logs of cores of test holes drilled by the U.S. Bureau of Reclamation under contract to the Bureau of Land Management, and auger test holes drilled by the U.S. Geological Survey. Information on soils is summarized from a report by Brinlee (1975) and climatic data are summarized from a report by Holbrook (1975).

\section{Acknowledgments}

Appreciation is extended to residents of the area who provided information about their wells and permitted measurements of water levels and collection of water samples. 

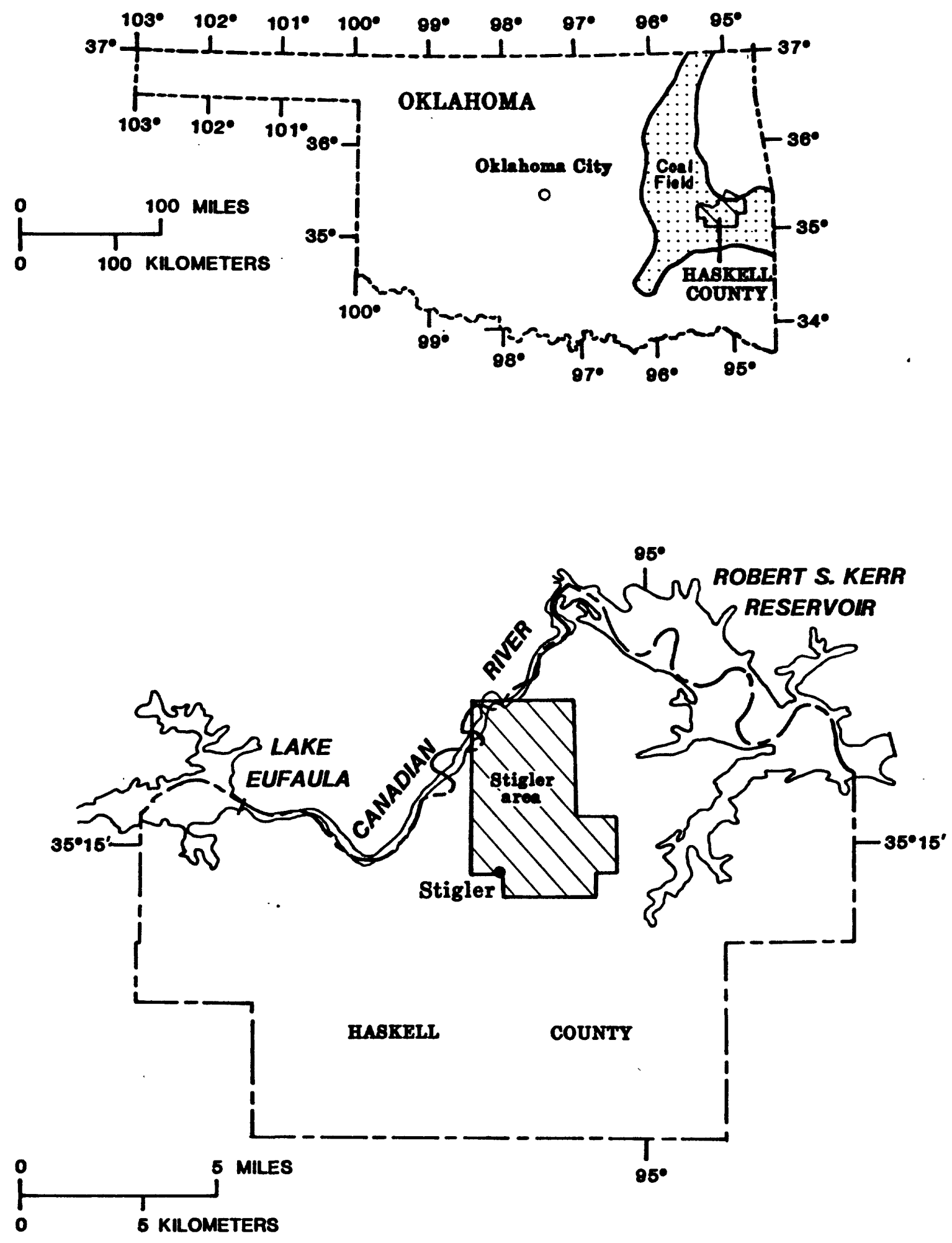

Figure 1. - Location of the Stigler area 
The standard method of describing the location of wells by fractional section, section, township, and range is illustrated in the diagram below. The location of the well indicated by the dot commonly would be described as NE 1/4, NE 1/4, NE 1/4, sec. 8, T. 9 N. R. 21 E. By the method used in this report, quarter subdivisions of the section are indicated by letters and the location of the well is given as 09N-21E-08 AAA 1 . The final digit (1) is the sequential number of a well within the smallest fractional subdivision.

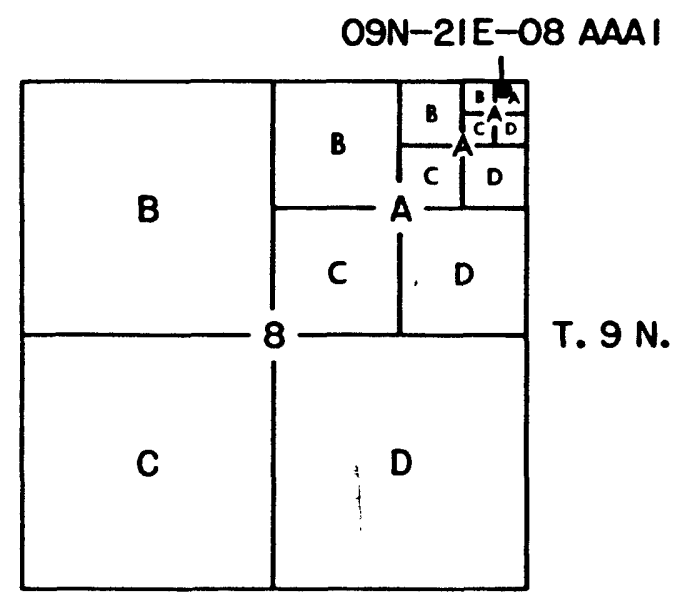

R. $21 \mathrm{E}$.

\section{Geographic Setting}

The Stigler area is in the McAlester marginal hills geomorphic province (Johnson and others, 1972) and is in the Arkoma geologic basin. In this province, the rocks have been folded to form east-trending anticlines and synclines. The landscape is characterized by irregular hills and ridges generally capped by erosion-resistant sandstones and covered with scrubby trees and brush. The intervening broad valleys have been formed by weathering and erosion of thick, easily-eroded shales and are vegetated with native grasses, shrubs, wild flowers, and weeds. Much of the valley area consists of improved pasture land used for livestock grazing.

\section{Climate}

The area has a warm, temperate climate. Spring and autumn are usually mild and summers are long and hot. Winters are comparatively mild, al though cold air keeps the temperature below freezing 7 days each year (Holbrook, 1975). Average annual precipitation is about 43 in. On the average, 35 percent of the year's total moisture falls during the spring, 27 percent during summer, 23 percent during autumn, and 15 percent during winter. Much of the rainfall results from short-duration thunderstorms of varying intensity which commonly occur during April, May, and June, but can occur during any month of the year. The average date of the last freeze, in the spring is March 30 and that of the first freeze in autumn is November 4. Average annual lake evaporation is about 53 in. 
The ocurrence, movement, and storage of ground water in the stigler area largely is controlled by the lateral and vertical distribution of rock units and their physical characteristics, especially permeability, and by the geologic structure.

Bedrock in most of the area is shale, siltstone, and sandstone of the McAlester, Savanna, and Boggy Formations, a small area north of the Mudlark fault is underlain by shale of the Atoka Formation (plate 1). All formations are of Pennsylvanian age. Most wells in the area obtain water from the McAlester Formation (table 1). Core-drill holes, auger holes, and onsite observations show that much of the shale is silty and includes beds of shaly and silty sandstone a few inches to a few feet thick. Sandstone units, which comprise about 30 percent of the total thickness of exposed rocks, actually consist of interbedded sandstone, siltstone and shale. Layers of sandstone are very fine to fine grained (particle diameters 0.062 to $0.25 \mathrm{~mm}$ ), are poorly to well cemented with silica and iron oxide, and contain beds of shale.

Structurally, the area is dominated by the northeast-trending Stigler sycline and the adjacent Antioch anticline (plate 1). Because of the geologic structure, the rock layers are tilted at the surface exposing bedding plane openings between layers of sandstone and partings between laminae of shale; these opening are the main avenues of water entry and movement. 0ther openings for water movement are fractures and joints developed during folding and faulting of the brittle rocks. Faults al so may be water conduits but if the rocks are so greatly crushed that the openings are sealed, the faults may be water barriers.

Terrace deposits, a few inches to about $25 \mathrm{ft}$ thick, occupy an area of several square miles between the town of Stigler and Morgan Mountain (plate 1). These deposits consist largely of sandy and clayey silt containing irregular layers of fine sand. Locally, the terrace deposits include beds of volcanic ash a few inches thick (Oakes and knechtel, 1948). The terrace deposits are well above water table and, therefore, have little hydrologic significance except that they may facilitate or hinder recharge to the underlying bedrock. Alluvium, which occurs as discontinuous strips and patches 5 to $10 \mathrm{ft}$ thick along Taloka and Jackson Creeks, consists of sandy silt and has no hydrologic significance.

Water-table conditions probably exist in the zone of weathered bedrock which extends to a depth of about $30 \mathrm{ft}$ in some parts of the area. Below the weathered zone the water is confined. Because of the confining pressure, water rises in wells and in most of the area is less than $30 \mathrm{ft}$ below the 1 and surface as shown by the potentiometic contours (plate 2) which are drawn for that part of area where adequate water-level data are available.

Neither the terrace deposits nor the alluvium are a source of water to wells. Although the bedrock has minimal permeability and storage capacity, wells in some parts of the area, ranging in depth from 34 to $235 \mathrm{ft}$ and averaging about $95 \mathrm{ft}$, yield enough water for domestic or livestock supplies. No tests to determine well yields in the area have been made. However, tests of wells penetrating similar rocks elsewhere in the coal field show that most wells yield less than $5 \mathrm{gal} / \mathrm{min}$. Because of the difficulty in obtaining an adequate domestic supply from wells in much of the area, water is provided by a rural water system (plate 2 ). 


\section{Recharge and Discharge}

Ground-water recharge is derived entirely from precipitation falling directly on or near the area. Although, on the average, approximately 60 percent of the precipitation falls during spring and summer, measurements of ground-water levels in various parts of the coal field show that little recharge takes place at the time because most of the water is lost by evapotranspiration before it can reach the saturated zone. Consequently, the ground-water level, which reflects the volume of water in storage, typically is lowest during late summer or autumn and is highest in late spring or early summer. Intermittent rains of 1-2 in. during summer, when evapotranspiration is greatest, may produce sharp but only temporary rises in the water level.

Data available for the Stigler area are not adequate to make an estimate of the volume of recharge or the volume of evapotranspiration. However, recharge in the Blocker area, which is about $30 \mathrm{mi}$ southwest and is hydrologically similar to the Stigler area, has been estimated at about $2 \mathrm{acre}-\mathrm{ft} / \mathrm{mi}^{2}$ per year (Marcher and others, 1982). Recharge in the Stigler area probably is less than this because the rocks may be less permeable than in the Blocker area. Evapotranspiration in the Stigler area probably is similar to that in the Blocker area, which has been estimated at about 80 percent of the average annual precipitation; the percentage varies from year to year, however, depending on climatic conditions. 


\section{SURFACE WATER}

\section{Stream-Discharge Characteristics}

Collection of stream-discharge data at two sites on Taloka Creek and a small tributary of Taloka Creek began in October, 1978; 1ocations of datacollection sites are shown on plate 2 and the available discharge records are given in tables 2,3 , and 4 . Because the predominantly shale bedrock lacks the capacity to store water, streams in the area are ephemeral and most of their discharge is the result of storm runoff lasting a few hours or days after precipitation. During most of the period of record, however, flow at the downstream site on Taloka Creek (station 07245030) was maintained by water pumped from an active coal mine and discharged into the creek. Discharge at the downstream site was less than $5 \mathrm{ft}^{3} / \mathrm{s}$ for 45 consecutive days in August and September, 1979. Daily flows of $10 \mathrm{ft}^{3} / \mathrm{s}$ or greater had a duratjon of less than 1 week. Mean annual flow for the 1979 water year was 16.5 $f t^{3} / \mathrm{s}$.

\section{Flood Frequencies}

As described by Sauer (1974), the relation of flood-peak magnitude to probability of occurrence, or recurrence interval generally is referred to as a flood-frequency relation. Probability of occurrence is the percent chance of a given flood magnitude being exceeded in any 1 year. Recurrence interval is the reciprocal of probability of occurrence times 100 , and is the average number of years between exceedances. It is emphasized that recurrence interval is an average interval. For example, a flood having a probability of occurrence of 2 percent has a recurrence interval of 50 years. This does not mean that each 50 years this flood will be exceeded, but that over a long period of time it will be exceeded on the average once every 50 years.

Computed flood frequencies for Taloka Creek, which were estimated using previously derived regression equations (Thomas and Corley, 1977), are given below. The regression equations relate basin characteristics to the expected frequency of the computed flood discharge. Basin characteristics for Taloka Creek are: drainage area, $20.1 \mathrm{mi}^{2}$; channel slope, $27.2 \mathrm{ft} / \mathrm{mi}$; annual precipitation, $43 \mathrm{in.}$ The maximum recorded instantaneous discharge for the 1979 water year was $717 \mathrm{ft}^{3} / \mathrm{s}$ on June 2 . The computed flood frequencies are:

Estimated recurrence interval (years)
Instantaneous discharge

(cubic feet per second)

$\begin{array}{rr}2 & 2,350 \\ 5 & 4,120 \\ 10 & 5,710 \\ 25 & 7,790 \\ 50 & 9,290 \\ 100 & 11,280\end{array}$




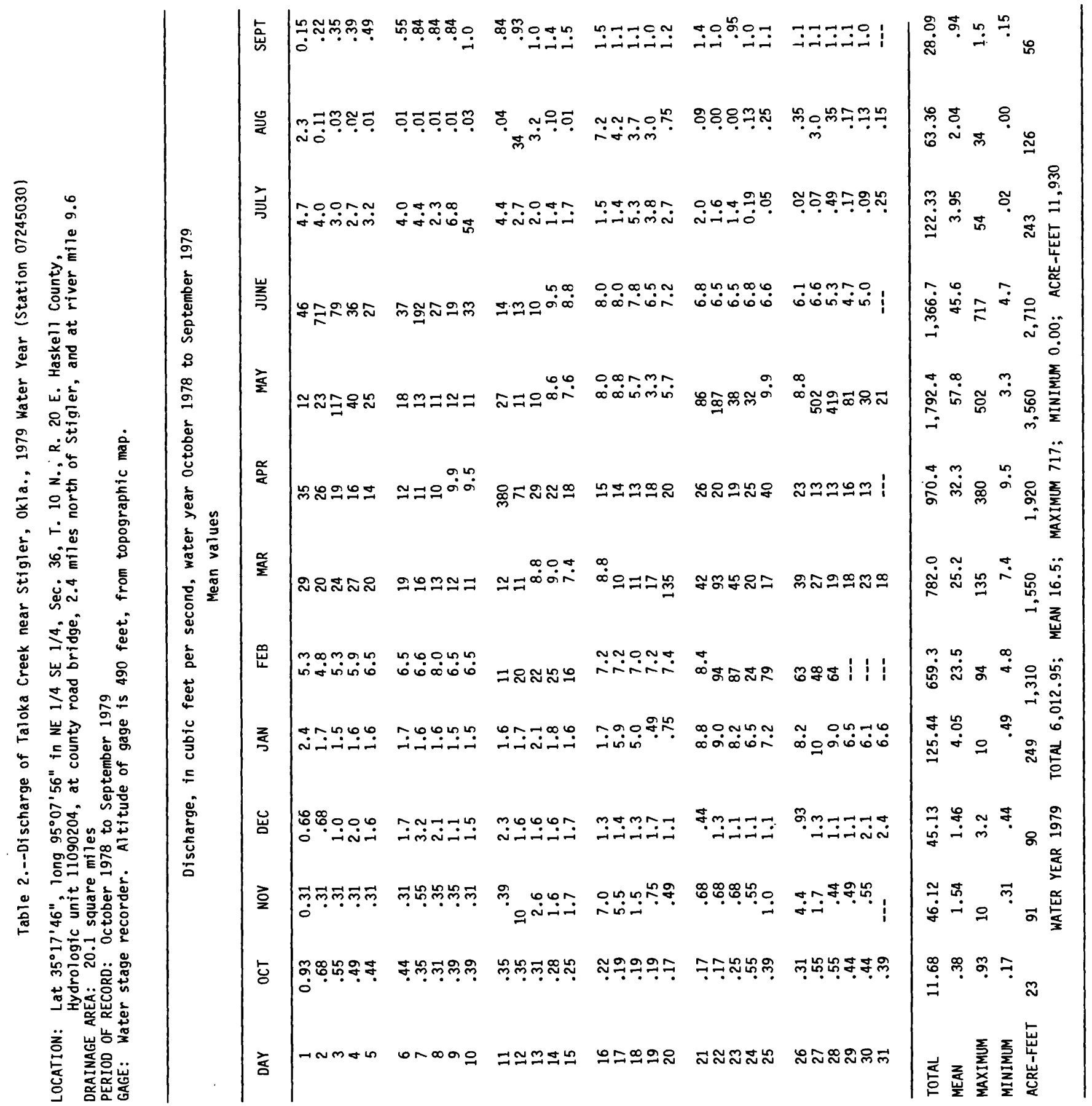


Table 3.--Discharge of Taloka Creek tributary near Stigler, Okla, 1979 water year (station 07245025).

LOCATION: Lat $35^{\circ} 17^{\prime} 13^{\prime \prime}$, long $95^{\circ} 07^{\prime} 00^{\prime \prime}$, on west line NW $1 / 4$, sec. 5 , T. $9 \mathrm{~N}$. R. 21 E., Haskel1 County, Hydrologic unit 11090204, at county road bridge, 1.8 miles north of Stigler.

DRAINAGE AREA: 3.98 square miles.

PERIOD OF RECORD: November 1978 to September 1979.

Water year November 1978 to September 1979

Date

Time

Discharge

(cubic feet per second)

\begin{tabular}{lrll}
\hline Nov. & 22 & 1130 & 0.00 \\
Dec. & 5 & 1245 & 2.4 \\
Feb. & 1 & 1345 & .86 \\
Mar. & 1 & 1400 & 2.1 \\
Mar. 13 & 0845 & 1.9 \\
& & 1130 & 1.9 \\
Mar. 24 & 1715 & 3.5 \\
Apr. 10 & 1535 & 2.4 \\
Apr. 24 & 1000 & 2.6 \\
May & 4 & 1055 & 2.9 \\
June 26 & 1110 & 2.5 \\
Ju1y & 12 & 1620 & 3.4 \\
Aug. 16 & 1300 & 1.8 \\
Sept. 17 & 1145 & 1.7 \\
Sept. 26 & & \\
\hline
\end{tabular}


Table 4.--Discharge of Taloka Creek at Stigler, Ok1a., 1979 water year (station 07245020).

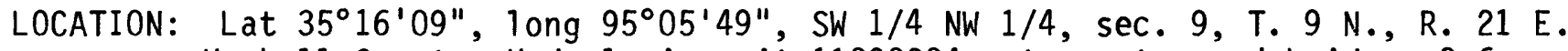
Haske11 County, Hydrologic unit 11090204, at county road bridge, 0.6 mile north of State Highway $9,1.6$ miles northeast of Stigler, and at river mile 14.0 .

DRAINAGE AREA: 3.98 Square miles.

PERIOD OF RECORD: December 1978 to September 1979.

Water year October 1978 to September 1979

Date

Time

Discharge

(cubic feet per second)

$\begin{array}{lrrc}\text { Oct. } & 20 & ---- & 0.00 \\ \text { Nov. } & 22 & ---- & .00 \\ \text { Dec. } & 5 & 0845 & .38 \\ \text { Dec. } & 20 & 1530 & .31 \\ \text { Feb. } & 1 & 0950 & 1.3 \\ & & & \\ \text { Feb. } & 15 & 0830 & 3.9 \\ \text { Mar. } & 1 & 1545 & 7.2 \\ \text { Mar. } & 12 & 1815 & 2.6 \\ \text { Mar. } & 24 & 1000 & 6.0 \\ \text { Apr. } & 11 & 1110 & 586 \\ & & & \\ \text { Apr. } & 24 & 1330 & 5.8 \\ \text { May } & 4 & 0820 & 8.5 \\ \text { May } & 29 & 1430 & .72 \\ \text { June } & 6 & 1200 & 6.8 \\ \text { June } & 22 & 1135 & .12 \\ & & & .14 \\ \text { July } & 12 & 0930 & .00 \\ \text { Aug. } & 16 & ---- & .00 \\ \text { Aug. } & 28 & 1230 & .00 \\ \text { Sept. } 17 & 1220 & .00 \\ \text { Sept. } 26 & 1100 & \end{array}$




\section{Flood-Prone Areas}

Large storms generate high streamflows that inundate flood-plains adjacent to stream channels. Approximate boundaries of flood-prone areas can be delineated when water-surface profiles are known or can be computed or when regional equations are available for computation of flood depths for various recurrence intervals. Regional equations (Thomas, 1976) were used to compute the 100-year flood depths for Taloka and Jackson Creeks (plate 3). Approximate boundaries of the 100-year flood-prone areas were delineated on the topographic map as indicated by the computed flood depths. The approximate 100-year flood-prone area corresponds to the area where there is a 1-in-100 chance of flooding during any year. 


\section{WATER QUALITY}

Al1 natural waters contain mineral constituents dissolved from the rock and soil with which the water has been in contact. The concentration of dissolved constituents largely depends on the type of rock or soil, the length of contact time, and pressure and temperature conditions. In addition to these natural conditions, man's activities, such as disposal of wastes, agricultural practices, and activities associated with mineral or fuel production can have a significant effect, generally adverse, on the chemical quality of water.

The Stigler area is mostly rural and although the town of stigler is partly within the basin of Taloka Creek, its sewage lagoon is outside the basin. The unwooded lands are used for cattle grazing and, other than home gardens and limited cutting of hay, there were no agricultural activities within the area during 1978-80. Timber cutting on a small scale is done locally. No gas or oil wells had been drilled as of the latter part of 1980 . Coal had been surface mined in Taloka Creek basin prior to 1958 and surface mining was active in the area from the time data collection started until October 1980. As described in later sections of this report, surface mining has caused significant changes in the chemical quality of water in Taloka Creek. In addition, excessive concentrations of toxic metals, from unknown sources, have been present from time to time in reaches of Taloka Creek upstream from the area of mining.

In natural waters, the major cations-- calcium, magnesium, and sodium plus potassium --and the major anions-- carbonate/bicarbonate, chloride, and sulfate--generaliy constitute more than 95 percent of the total ions in solution. Water can be typed according to the percentage of each of the major ions. For example, in a calcium sulfate type water, calcium constitutes more than 50 percent of the cations and sulfate constitutes more than 50 percent of the anions. If none of the cations or anions constitutes more than 50 percent of its respective ion group, the water is described as a mixed type.

\section{Ground Water}

Data on the chemical quality of ground water in the Stigler area are limited to onsite determinations of specific conductance and $\mathrm{pH}$ and laboratory determinations of chloride, sulfate, iron, and manganese (table 1).

Specific-conductance measurements provide a means of estimating the concentration of dissolved solids in water where that concentration has not been directly determined. The average ratio of measured dissolved-solids concentration to the specific conductance in water samples from various parts of the coal field ranged from 0.60 to 0.65 . In the Blocker area, which is geologically similar to the Stigler area, the ratio was 0.63 ; this value is considered reasonable for the Stigler area. By multiplying the specific conductance, as determined onsite, by 0.63 , dissolved solids concentrations in the Stigler area ranged from approximately 200 to $2,500 \mathrm{mg} / \mathrm{L}$ with a mean of about $550 \mathrm{mg} / \mathrm{L}$. The large variation in the estimated dissolved-solids concentrations does not have any apparent relationship to well depth, geographic distribution, or geologic formation. 


\section{Surface Water}

\section{Water Type}

A trilinear diagram (fig. 2) of average concentrations of common constituents shows that water from Taloka Creek at Stigler is a mixed type whereas water from Taloka Creek tributary and Taloka Creek near Stigler are sodium sulfate types and are virtually identical chemically. The marked increase in sodium and sulfate between the upstream and downstream sites may be explained as follows: first, water from the mine or in contact with the spoil dissolves gypsum from the shale producing calcium and sulfate in solution; second, contact of the calcium-sulfate bearing water with clay minerals results in an ion exchange reaction with calcium being replaced by sodium to produce sodium sulfate type water. Another possible explanation is that sulfate is produced by the oxidation of pyrite but such oxidation does not account for the increase in sodium. Furthermore, if the oxidation mechanism were significant, the change in $\mathrm{pH}$ and dissolved iron concentrations between the upstream and downstream sites would be much greater.

\section{Constituent Concentrations}

Tables 5, 6 and 7, which summarize data available prior to September, 1980, show that dissolved-solids concentrations in Taloka Creek at Stigler (station 07245020) ranged from 54 to $96 \mathrm{mg} / \mathrm{L}$ (milligrams per liter) with a mean of $72 \mathrm{mg} / \mathrm{L}$ whereas dissolved solids concentrations from Taloka Creek near Stigler (station 07245030) ranged from 57 to $2,340 \mathrm{mg} / \mathrm{L}$ with a mean of $1,323 \mathrm{mg} / \mathrm{L}$. The largest increases in concentrations were for sodium and sulfate; the mean concentrations of these constituents increased about 40-fold from the upstream to the downstream site.

Statistical analysis of concentrations of the common constituents in samples collected before September 1980 , showed that there was (1) a significant difference in dissolved solids, calcium, magnesium, potassium, alkalinity, and chloride between the upstream and downstream sites, (2) a significant difference in dissolved solids, calcium, mangesium, potassium, and alkalinity between the upstream site and Taloka Creek tributary, and (3) no significant difference in the chemistry of the water from the tributary and the downstream site.

Because of frequent no-flow conditions since September 1980, only six samples were collected at the upstream site and nine samples were collected at the downstream site; determinations made on these samples are given in tables 8 and 9.

Selected physical properties and chemical constituents of samples collected from the upstream and downstream sites on the same day and at about the same time are compared in table 10. The comparison shows that al though specific conductances, $\mathrm{pH}$, and dissolved-solids concentrations increased downstream in all three sets of samples, the increase was large only in the samples collected on February 5. However, in all three sets of samples, total recoverable iron, dissolved manganese, and total recoverable manganese increased greatly. No relation between stream discharge and changes in water chemistry is apparent; however, the stream discharge data are limited in the range of flows. The data are not adequate to determine the causes of variations in water chemistry with time. 


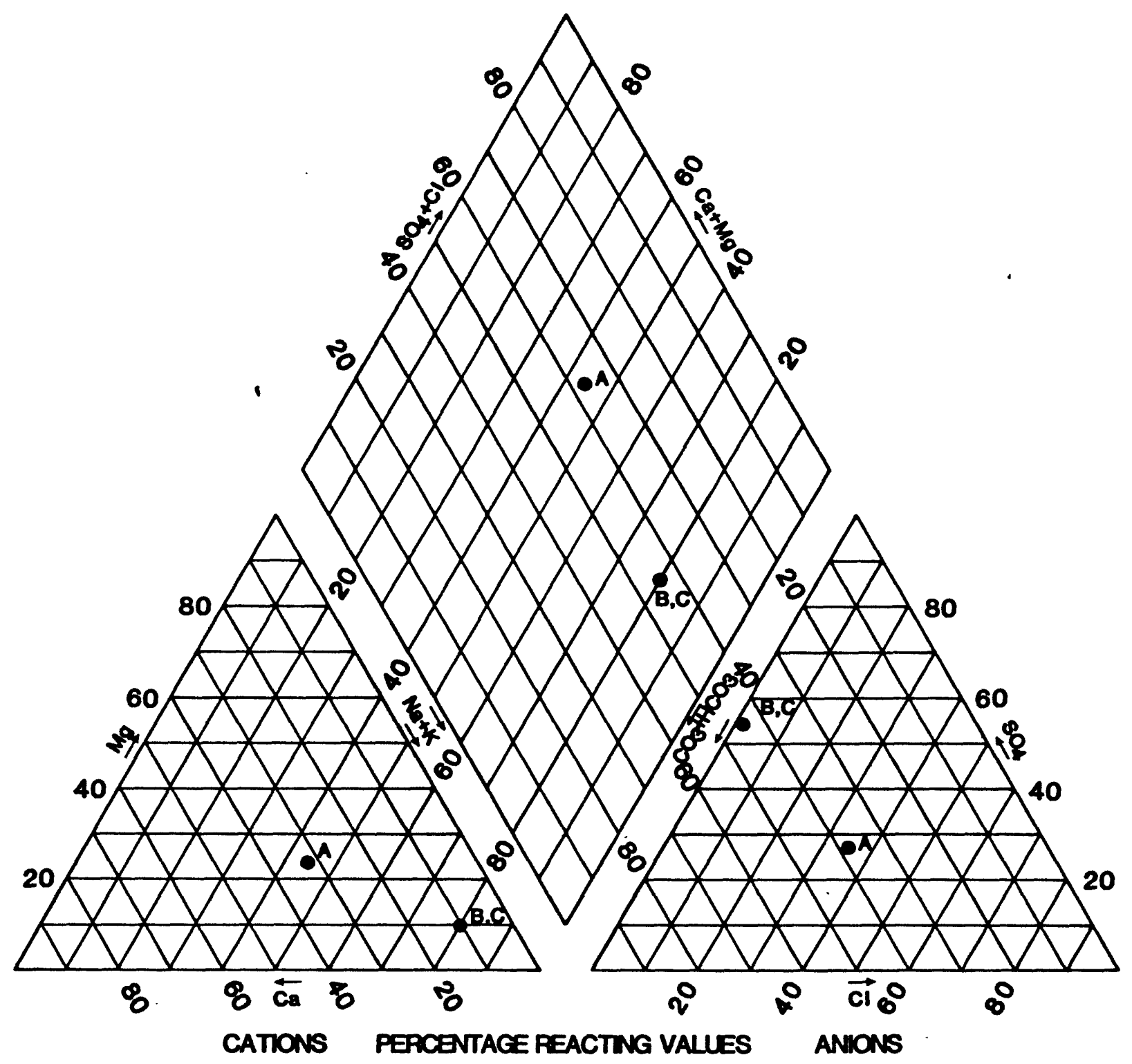

Figure 2. - Trilinear diagram of average concentrations of common constituents in surface water in the Stigler area. A, Taloka Creek at Stigler (station 07245020); B, Taloka Creek tributary (station 07245025); and C, Taloka Creek near Stigler (station 07245030). 
Table 5.--Mean, minimum, and maximum values for selected physical properties and chemical constituents, 1979 water year, for water from Taloka Creek near Stigler (station 07245030).

[micromhos, micromhos per centimeter at $25^{\circ}$ Cel sius; ROE, residue on evaporation at $180^{\circ}$ Celsius; $\mathrm{mg} / \mathrm{L}$, milligrams per liter, $\mu \mathrm{g} / \mathrm{L}$, micrograms per liter.]

\begin{tabular}{|c|c|c|c|c|}
\hline Constituent & $\begin{array}{c}\text { Number of } \\
\text { determinations }\end{array}$ & Mean & Minimum & Maximum \\
\hline Specific conductance (micromhos) & 36 & 1,845 & 58 & 3,140 \\
\hline $\begin{array}{l}\text { pH (units) } \\
\text { Dissolved solids (ROE) }\end{array}$ & $\begin{array}{l}36 \\
19\end{array}$ & 1,323 & $\begin{array}{l}6.8 \\
57\end{array}$ & $2,340^{8.6}$ \\
\hline Hardness $\left(\mathrm{CaCO}_{3}\right)(\mathrm{mg} / \mathrm{L})$ & 19 & 214 & 20 & 440 \\
\hline Bicarbonate $\left(\mathrm{HCO}_{3}\right)(\mathrm{mg} / \mathrm{L})$ & --- & --- & --- & --- \\
\hline Carbonate $\left(\mathrm{CO}_{3}\right)(\mathrm{mq} / \mathrm{L})$ & --- & --- & --- & - \\
\hline Dissolved calcium (Ca) (mg/L) & 19 & 43 & 5.7 & 77 \\
\hline Dissolved magnesium $(\mathrm{Mg})(\mathrm{mg} / \mathrm{L})$ & 19 & 26 & 1.4 & 71 \\
\hline Dissolved sodium $(\mathrm{Na})(\mathrm{mg} / \mathrm{L})$ & 19 & 393 & 3.9 & 770 \\
\hline Dissolved potassium $(\mathrm{K})(\mathrm{mg} / \mathrm{L})$ & 19 & 3.5 & 2.0 & 4.5 \\
\hline Dissolved chloride (Cl) $(\mathrm{mg} / \mathrm{L})$ & 19 & 26 & 3.8 & 84 \\
\hline Dissolved sulfate $\left(\mathrm{SO}_{4}\right)(\mathrm{mg} / \mathrm{L})$ & 19 & 543 & 11 & 1,200 \\
\hline Dissolved fiuoride $(\mathrm{F})(\mathrm{mg} / \mathrm{L})$ & 19 & 0.25 & 0.1 & 0.4 \\
\hline Dissolved arsenic (As) $(\mu \mathrm{g} / \mathrm{L})$ & 32 & 1.8 & 0 & 6.0 \\
\hline Total recoverable arsenic (As) $(\mu \mathrm{g} / \mathrm{L})$ & 31 & 2.5 & 1.0 & 7.0 \\
\hline Dissolved boron (B) $(\mu \mathrm{g} / \mathrm{L})$ & 30 & 396 & 40 & 770 \\
\hline Total recoverable boron $(B)(\mu \mathrm{g} / \mathrm{L})$ & 30 & 422 & 50 & 850 \\
\hline Dissolved cadmium $(C d)(\mu \mathrm{g} / \mathrm{L})$ & 28 & 1.2 & 0 & 10 \\
\hline Total recoverable cadmium $(\mathrm{Cd})(\mu \mathrm{g} / \mathrm{L})$ & 31 & 3 & 0 & 30 \\
\hline Dissolved chromium $(\mathrm{Cr})(\mu \mathrm{g} / \mathrm{L})$ & 32 & 3.4 & 0 & 20 \\
\hline Total recoverable chromium $(\mathrm{Cr})(\mu \mathrm{g} / \mathrm{L})$ & 31 & 5 & 0 & 20 \\
\hline Dissolved copper $(\mathrm{Cu})(\mu \mathrm{g} / \mathrm{L})$ & 27 & 1.4 & 0 & 10 \\
\hline Total recoverable copper $(\mathrm{Cu})(\mu \mathrm{g} / \mathrm{L})$ & 31 & 17 & 0 & 83 \\
\hline Dissolved iron $(\mathrm{Fe})(\mu \mathrm{g} / \mathrm{L})$ & 32 & 89 & 10 & 370 \\
\hline Total recoverable iron $(\mathrm{Fe})(\mu \mathrm{g} / \mathrm{L})$ & 32 & 2,123 & 400 & 10,000 \\
\hline Dissolved lead $(\mathrm{Pb})(\mu \mathrm{g} / \mathrm{L})$ & 27 & 23 & 0 & 300 \\
\hline Total recoverable lead $(\mathrm{Pb})(\mu \mathrm{g} / \mathrm{L})$ & 31 & 39 & 0 & 200 \\
\hline Dissolved mercury $(\mathrm{Hg})(\mathrm{ug} / \mathrm{L})^{\text {ast }}$ & 32 & 2 & 0 & 53 \\
\hline Total recoverable mercury $(\mathrm{Hg})(\mu \mathrm{g} / \mathrm{L})$ & 31 & 1.8 & 0 & 36 \\
\hline Dissolved manganese $(M n)(u \mathrm{q} / \mathrm{L})$ & 32 & 169 & 10 & 780 \\
\hline Total recoverable manganese $(\mathrm{Mn})(\mu \mathrm{g} / \mathrm{L})$ & 32 & 261 & 50 & 940 \\
\hline Dissolved molybdenum (Mo) $(\mu \mathrm{g} / \mathrm{L})$ & 25 & 3.6 & 0 & 14 \\
\hline Total recoverable molybdenum (Mo) $(\mu \mathrm{g} / \mathrm{L})$ & 32 & 3.5 & 0 & 14 \\
\hline Dissolved nickel $(\mathrm{Ni})(\mu \mathrm{g} / \mathrm{L})$ & --- & --- & -- & -- \\
\hline Total recoverable nickel $(\mathrm{Ni})(\mu \mathrm{g} / \mathrm{L})$ & --- & --- & --- & -- \\
\hline Dissolved zinc $(Z n)(\mu \mathrm{g} / \mathrm{L})$ & 27 & 15 & 0 & 30 \\
\hline Total recoverable zinc $(\mathrm{Zn})(\mu \mathrm{g} / \mathrm{L})$ & 31 & 29 & 0 & 90 \\
\hline Dissolved aluminum $(A T)(\mu \mathrm{g} / \mathrm{L})$ & 32 & 72 & 0 & 1,000 \\
\hline Total recoverable aluminum (Al) $(\mu \mathrm{g} / \mathrm{L})$ & 32 & 1,517 & 0 & 8,700 \\
\hline Dissolved nitrogen $(\mathrm{N})(\mathrm{mg} / \mathrm{L})$ & 15 & 5.6 & .8 & 14 \\
\hline Total nitrogen $(\mathrm{N})(\mathrm{mg} / \mathrm{L})$ & 18 & 9.5 & .9 & 51 \\
\hline
\end{tabular}


Table 6.--Mean, minimum, and maximum values for selected physical properties and chemical constituents, 1979 water year, for water from Taloka Creek tributary near Stigler (07245025).

[micromhos, micromhos per centimeter at $25^{\circ}$ Celsius; ROE, residue on evaporation at $180^{\circ}$ Celsius; $\mathrm{mg} / \mathrm{L}$, milligrams per 1iter; $\mu \mathrm{g} / \mathrm{L}$, micrograms per $1 \mathrm{iter} .1$

\begin{tabular}{|c|c|c|c|c|}
\hline Constituent & $\begin{array}{c}\text { Number of } \\
\text { determinations }\end{array}$ & Mean & Minimum & Maximum \\
\hline Specific conductance (micromhos) & 28 & 2,635 & 550 & 3,550 \\
\hline $\mathrm{pH}$ (units) & 29 & -- & 7.7 & 8.8 \\
\hline Dissolved solids (ROE) & 8 & 1,766 & 318 & 2,300 \\
\hline Hardness $\left(\mathrm{CaCO}_{3}\right)(\mathrm{mg} / \mathrm{L})$ & 8 & 279 & 130 & 510 \\
\hline Bicarbonate $\left(\mathrm{HCO}_{3}\right)(\mathrm{mg} / \mathrm{L})$ & --- & --- & --- & --- \\
\hline Carbonate $\left(\mathrm{CO}_{3}\right)(\mathrm{mg} / \mathrm{L})$ & --- & --- & -- & --- \\
\hline Dissolved calcium (Ca) (mg/L) & 8 & 56 & 25 & 110 \\
\hline Dissolved magnesium $(\mathrm{Mg})(\mathrm{mg} / \mathrm{L})$ & 8 & 34 & 12 & 56 \\
\hline Dissolved sodium $(\mathrm{Na})(\mathrm{mg} / \mathrm{L})$ & 8 & 542 & 66 & 700 \\
\hline Dissolved potassium (K) (mg/L) & 8 & 3.6 & 2.8 & 5.8 \\
\hline Dissolved chloride (Cl) (mg/L) & 8 & 41 & 12 & 99 \\
\hline Dissolved sulfate $\left(\mathrm{SO}_{4}\right)(\mathrm{mg} / \mathrm{L})$ & 8 & 707 & 64 & 970 \\
\hline Dissolved fluoride (F) (mg/L) & 8 & 0.4 & 0.2 & 0.6 \\
\hline Dissolved arsenic (As) ( $\mu \mathrm{g} / \mathrm{L})$ & 12 & 4 & 1 & 10 \\
\hline Total recoverable arsenic (As) $(\mu \mathrm{g} / \mathrm{L})$ & 12 & 4.7 & 1 & 11 \\
\hline Dissolved boron $(B)(\mu \mathrm{g} / \mathrm{L})$ & 12 & 588 & 370 & 660 \\
\hline Total recoverable boron (B) $(\mu \mathrm{g} / \mathrm{L})$ & 12 & 619 & 370 & 710 \\
\hline Dissolved cadmium $(\mathrm{Cd})(\mu \mathrm{g} / \mathrm{L})$ & 11 & 2.6 & 0 & 25 \\
\hline Total recoverable cadmium $(\mathrm{Cd})(\mu \mathrm{g} / \mathrm{L})$ & 12 & 5.4 & 0 & 25 \\
\hline Dissolved chromium $(\mathrm{Cr})(\mu \mathrm{g} / \mathrm{L})$ & 12 & 1.7 & 0 & 10 \\
\hline Total recoverable chromium $(\mathrm{Cr})(\mu \mathrm{g} / \mathrm{L})$ & 12 & 2.7 & 0 & 12 \\
\hline Dissolved copper (Cu) $(\mu \mathrm{g} / \mathrm{L})$ & 12 & 3.2 & 0 & 20 \\
\hline Total recoverable copper $(\mathrm{Cu})(\mu \mathrm{g} / \mathrm{L})$ & 12 & 23 & 0 & 63 \\
\hline Dissolved iron (Fe) $(\mu \mathrm{g} / \mathrm{L})$ & 12 & 48 & 10 & 130 \\
\hline Total recoverable iron $(\mathrm{Fe})(\mu \mathrm{g} / \mathrm{L})$ & 12 & 1,235 & 270 & 5,200 \\
\hline Dissolved lead $(\mathrm{Pb})(\mu \mathrm{g} / \mathrm{L})$ & 12 & 17 & 0 & 200 \\
\hline Total recoverable lead $(\mathrm{Pb})(\mu \mathrm{g} / \mathrm{L})$ & 12 & 58 & 0 & 300 \\
\hline Dissolved mercury $(\mathrm{Hg})(\mu \mathrm{g} / \mathrm{L})$ & 12 & .1 & 0 & 1.3 \\
\hline Total recoverable mercury $(\mathrm{Hg})(\mu \mathrm{g} / \mathrm{L})$ & 12 & .2 & 0 & 1.4 \\
\hline Dissolved manganese $(M n)(\mu g / L)$ & 12 & 115 & 30 & 380 \\
\hline Total recoverable manganese $(\mathrm{Mn})(\mu \mathrm{g} / \mathrm{L})$ & 12 & 209 & 50 & 560 \\
\hline Dissolved molybdenum (Mo) $(\mu \mathrm{g} / \mathrm{L})$ & 11 & 7.4 & 3 & 12 \\
\hline Total recoverable molybdenum (Mo) $(\mu \mathrm{g} / \mathrm{L})$ & 12 & 6.2 & 0 & 14 \\
\hline Dissolved nickel $(\mathrm{Ni})(\mu \mathrm{g} / \mathrm{L})$ & --- & --- & --- & --- \\
\hline Total recoverable nickel $(\mathrm{Ni})(\mu \mathrm{g} / \mathrm{L})$ & --- & -- & --- & --- \\
\hline Dissolved $\operatorname{zinc}(\mathrm{Zn})(\mu \mathrm{g} / \mathrm{L})$ & 12 & 23 & 5 & 60 \\
\hline Total recoverable zinc $(Z n)(\mu \mathrm{g} / \mathrm{L})$ & 12 & 43 & 10 & 130 \\
\hline Dissolved aluminum $(A])(\mu \mathrm{g} / \mathrm{L})$ & 12 & 46 & 0 & 180 \\
\hline Total recoverable aluminum $(A T)(\mu \mathrm{g} / \mathrm{L})$ & 12 & 820 & 0 & 2,900 \\
\hline Dissolved nitrogen (N) (mg/L) & 7 & 9.4 & 1.3 & 16 \\
\hline Total nitrogen $(\mathrm{N})(\mathrm{mg} / \mathrm{L})$ & 7 & 10 & 3 & 18 \\
\hline
\end{tabular}


Table 7.--Mean, minimum, and maximum values for selected physical properties and chemical constituents, 1979 water year, for water from Taloka Creek at Stigler (station 07245020).

[micromhos, micromhos per centimeter at $25^{\circ}$ Celsius; ROE, residue on evaporation at $180^{\circ} \mathrm{Celsius;} \mathrm{mg} / \mathrm{L}$, milligrams per 1 iter; $\mu \mathrm{g} / \mathrm{L}$, micrograms per $\left.1 \mathrm{iter}.\right]$

\begin{tabular}{|c|c|c|c|c|}
\hline Constituent & $\begin{array}{c}\text { Number of } \\
\text { determinations }\end{array}$ & Mean & Minimum & Maximum \\
\hline Specific conductance (micromhos) & 17 & 113 & 79 & 175 \\
\hline $\mathrm{pH}$ (units) & 17 & -- & 6.6 & 8.2 \\
\hline Dissolved solids (ROE) & 10 & 72 & 54 & 96 \\
\hline Hardness $\left(\mathrm{CaCO}_{3}\right)(\mathrm{mg} / \mathrm{L})$ & 10 & 30 & 24 & 43 \\
\hline Bicarbonate $\left(\mathrm{HCO}_{3}\right)(\mathrm{mg} / \mathrm{L})$ & --- & --- & --- & --- \\
\hline Carbonate $\left(\mathrm{CO}_{3}\right)(\mathrm{mg} / \mathrm{L})$ & --- & --- & -- & -- \\
\hline Dissolved calcium (Ca) (mg/L) & 10 & 6.9 & 5.5 & 9.5 \\
\hline Dissolved magnesium $(\mathrm{Mg})(\mathrm{mg} / \mathrm{L})$ & 10 & 3.1 & 2.4 & 4.8 \\
\hline Dissolved sodium ( $\mathrm{Na})(\mathrm{mg} / \mathrm{L})$ & 10 & 9 & 6.7 & 14 \\
\hline Dissolved potassium (K) (mg/L) & 10 & 2.3 & 1.4 & 5.2 \\
\hline Dissolved chloride (Cl) (mg/L) & 10 & 12 & 7.1 & 18 \\
\hline Dissolved sulfate $\left(\mathrm{SO}_{4}\right)(\mathrm{mg} / \mathrm{L})$ & 10 & 12 & 7.6 & 17 \\
\hline Dissolved fluoride (F) (ma/L) & 10 & 0.1 & 0 & 0.2 \\
\hline Dissolved arsenic (As) $(\mu \mathrm{g} / \mathrm{L})$ & 16 & .3 & 0 & 1 \\
\hline Total recoverable arsenic (As) $(\mu \mathrm{g} / \mathrm{L})$ & 16 & .6 & 0 & 2 \\
\hline Dissolved boron (B) $(\mu \mathrm{g} / \mathrm{L})$ & 16 & 24 & 10 & 40 \\
\hline Total recoverable boron $(B)(\mu \mathrm{g} / \mathrm{L})$ & 16 & 52 & 8 & 90 \\
\hline Dissolved cadmium $(\mathrm{Cd})(\mu \mathrm{g} / \mathrm{L})$ & 8 & 1.1 & 0 & 7 \\
\hline Total recoverable cadmium $(\mathrm{Cd})(\mu \mathrm{g} / \mathrm{L})$ & 16 & .8 & 0 & 13 \\
\hline Dissolved chromium $(\mathrm{Cr})(\mu \mathrm{g} / \mathrm{L})$ & 16 & .6 & 0 & 10 \\
\hline Total recoverable chromium $(\mathrm{Cr})(\mu \mathrm{g} / \mathrm{L})$ & 16 & 3.8 & 0 & 10 \\
\hline Dissolved copper $(\mathrm{Cu})(\mu \mathrm{g} / \mathrm{L})$ & 11 & 3.9 & 0 & 15 \\
\hline Total recoverable copper $(\mathrm{Cu})(\mu \mathrm{g} / \mathrm{L})$ & 16 & 10 & 0 & 50 \\
\hline Dissolved iron $(\mathrm{Fe})(\mu \mathrm{g} / \mathrm{L})$ & 16 & 161 & 40 & 360 \\
\hline Total recoverable iron $(\mathrm{Fe})(\mu \mathrm{g} / \mathrm{L})$ & 16 & 952 & 260 & 3,300 \\
\hline Dissolved lead $(\mathrm{Pb})(\mu \mathrm{g} / \mathrm{L})$ & 11 & 9 & 0 & 96 \\
\hline Total recoverable lead $(\mathrm{Pb})(\mu \mathrm{g} / \mathrm{L})$ & 16 & 19 & 0 & 100 \\
\hline Dissolved mercury $(\mathrm{Hg})(\mu \mathrm{g} / \mathrm{L})$ & 16 & 2.7 & 0 & 29 \\
\hline Total recoverable mercury $(\mathrm{Hg})(\mu \mathrm{g} / \mathrm{L})$ & 16 & 6 & 0 & 80 \\
\hline Dissolved manganese $(M n)(\mu \mathrm{g} / \mathrm{L})$ & 16 & 95 & 20 & 320 \\
\hline Total recoverable manganese $(\mathrm{Mn})(\mu \mathrm{g} / \mathrm{L})$ & 16 & 134 & 30 & 380 \\
\hline Dissolved molybdenum $\left(\mathrm{Mo}_{0}\right)(\mu \mathrm{g} / \mathrm{L})$ & 10 & .2 & 0 & 1 \\
\hline Total recoverable molybdenum $\left(\mathrm{Mo}_{0}\right)(\mu \mathrm{g} / \mathrm{L})$ & 16 & .06 & 0 & 1 \\
\hline Dissolved nickel $(\mathrm{Ni})(\mu \mathrm{g} / \mathrm{L})$ & --- & --- & -- & --- \\
\hline Total recoverable nickel $(\mathrm{Ni})(\mu \mathrm{g} / \mathrm{L})$ & --- & --- & --- & --- \\
\hline Dissolved $\operatorname{zinc}(Z n)(\mu \mathrm{g} / \mathrm{L})$ & 10 & 12 & 3 & 30 \\
\hline Total recoverable zinc $(\mathrm{Zn})(\mu \mathrm{g} / \mathrm{L})$ & 16 & 25 & 10 & 70 \\
\hline Dissolved aluminum $(A 1)(\mu \mathrm{g} / \mathrm{L})$ & 16 & 44 & 0 & 80 \\
\hline Total recoverable aluminum $(\mathrm{Al})(\mu \mathrm{g} / \mathrm{L})$ & 16 & 44 & 20 & 1,400 \\
\hline Dissolved nitrogen $(\mathrm{N})(\mathrm{mg} / \mathrm{L})$ & 8 & 1.4 & 0.5 & 3.1 \\
\hline Total nitrogen $(\mathrm{N})(\mathrm{mg} / \mathrm{L})$ & 8 & 1.3 & .5 & 3.2 \\
\hline
\end{tabular}




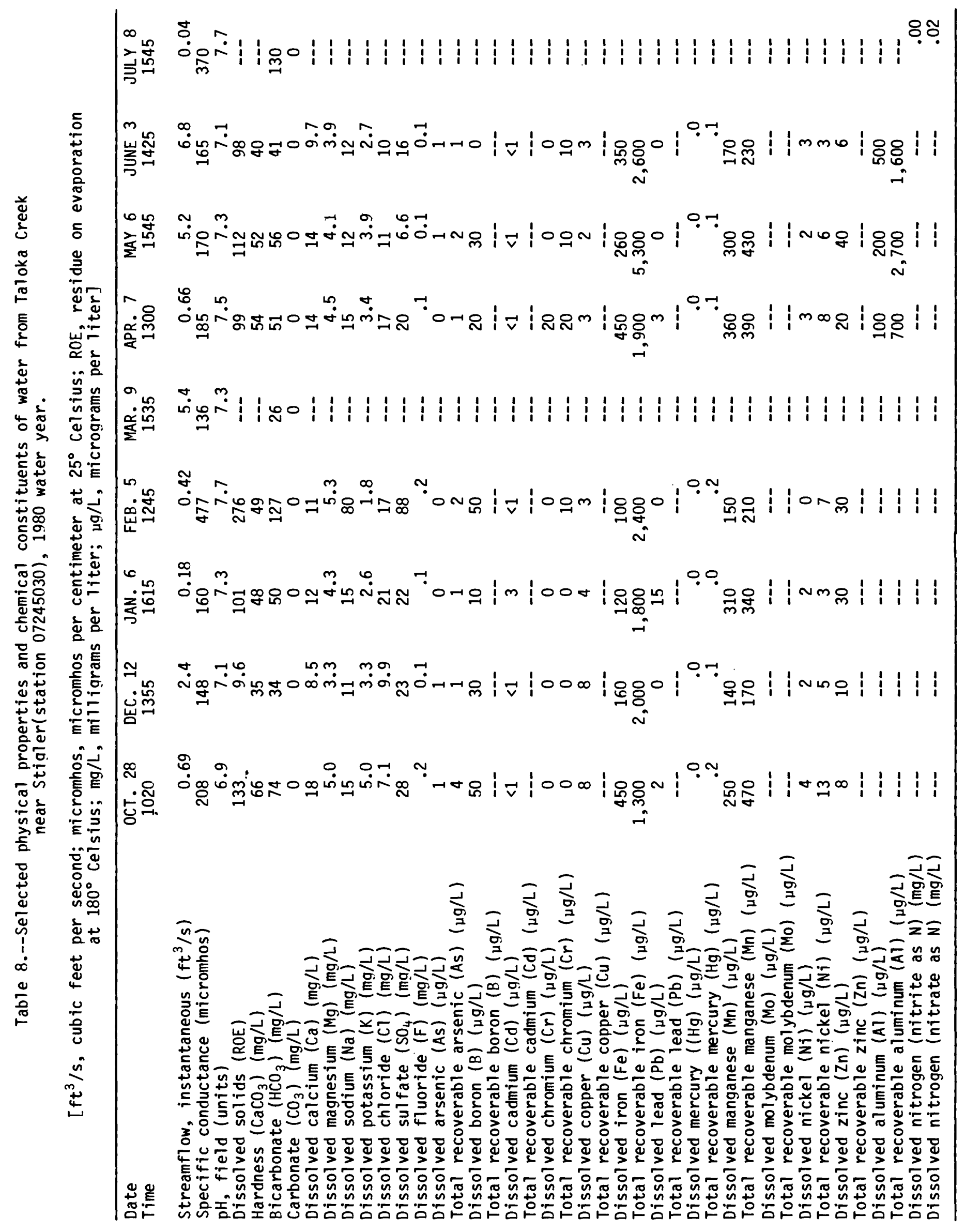




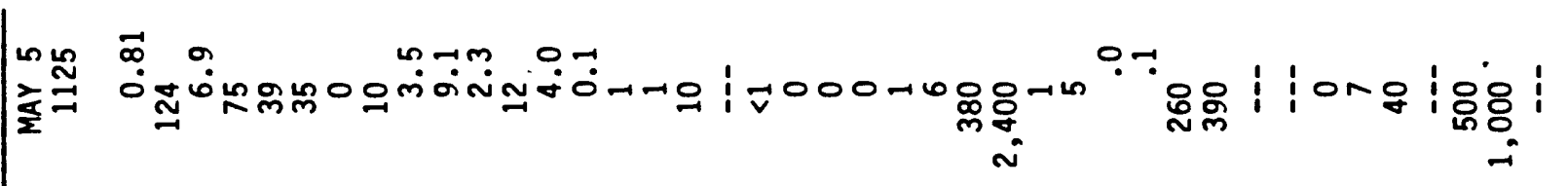

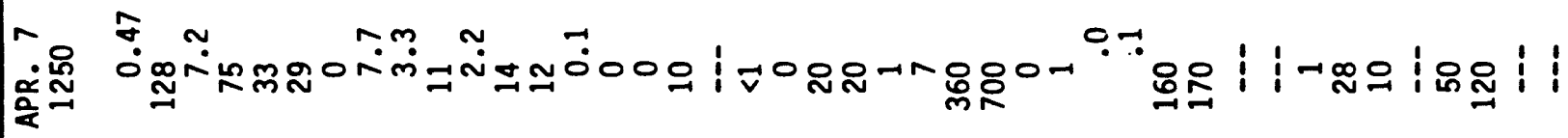

ธ

喜

这

H

$\approx$

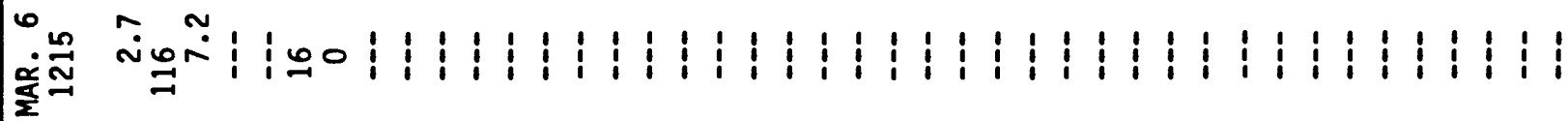

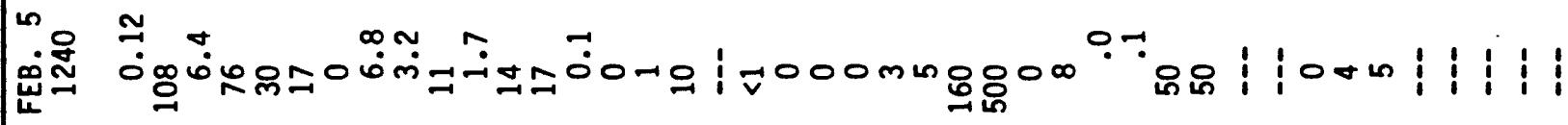

西

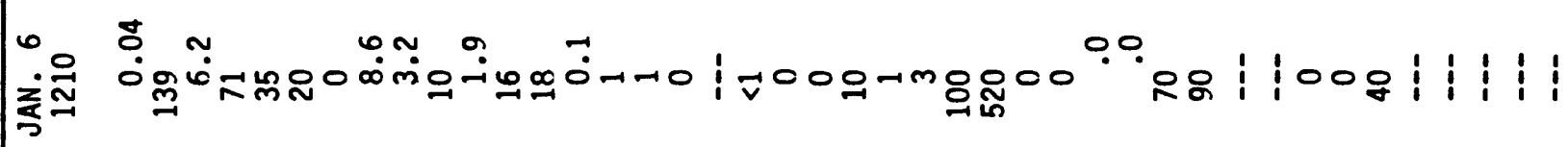

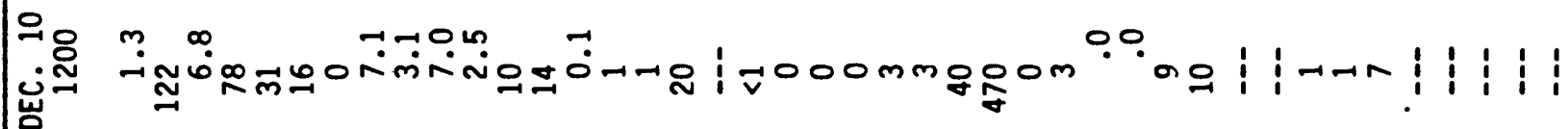

E

호

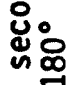

竞

ฆัँ

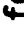

言

$\stackrel{5}{5}$

政

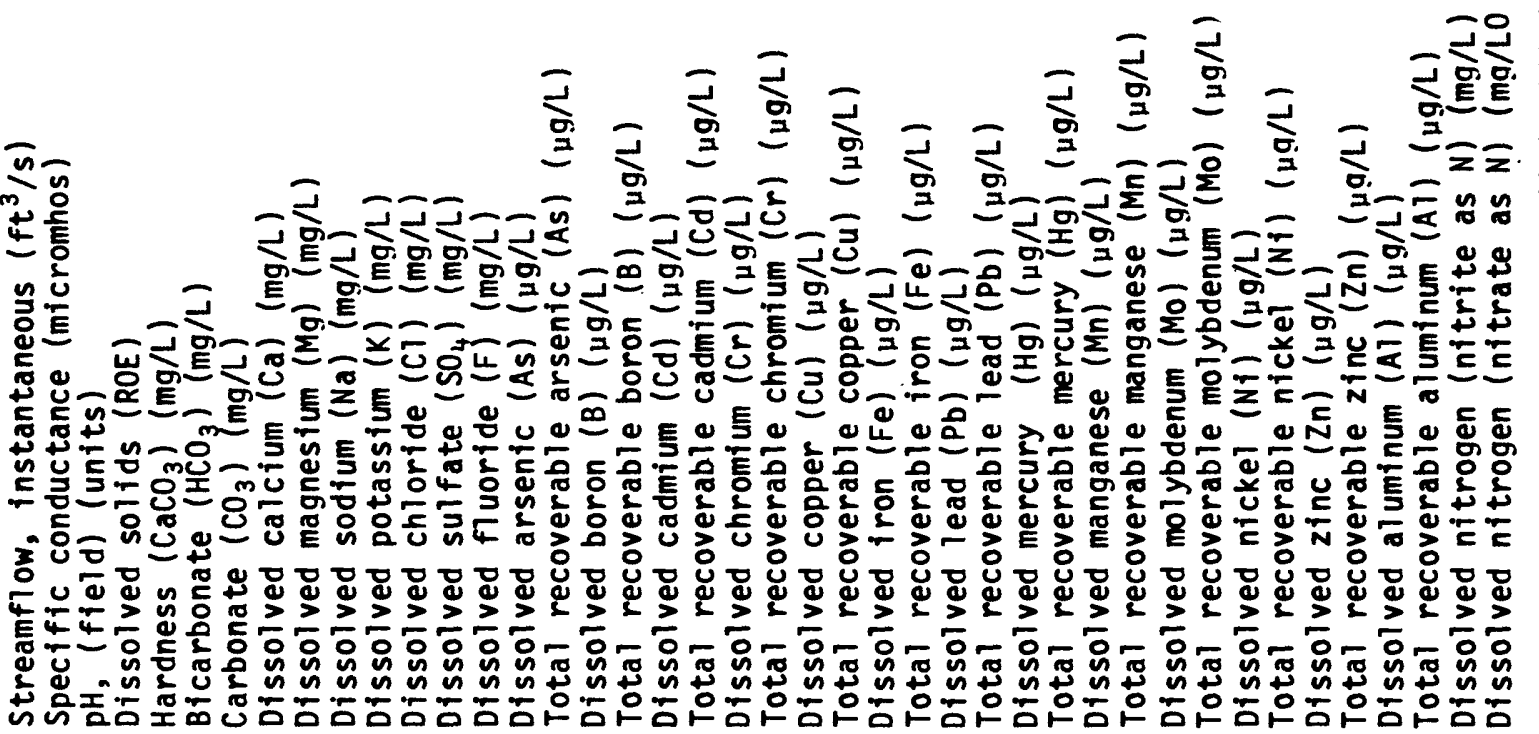




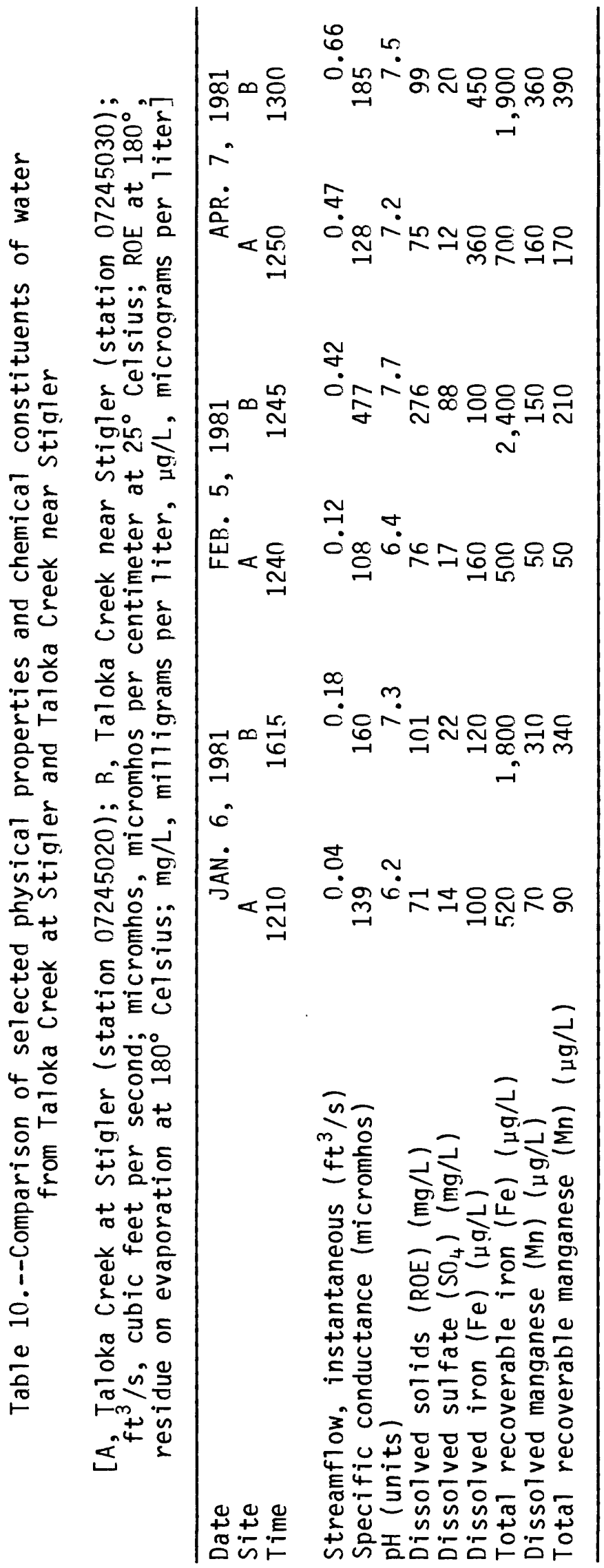


Trace metals

Maximum contaminant levels of toxic metals in domestic water supplies, as established by the U.S. Environmental Protection Agency (1976), in micrograms per liter $(\mu \mathrm{g} / \mathrm{L})$ are; arsenic, 50; cadmium, 10; chromium, 50; lead, 50; and mercury, 2.0. The available data on these metals along with iron, aluminum, and manganese in samples of water from Taloka Creek collected prior to September 1980 are summarized as follows:

Arsenic: Dissolved, suspended, and total concentrations of arsenic did not exceed the maximum containant level at any of the sites.

Cadmium: The maximum level for cadmium was exceeded in the dissolved phase in one sample from Taloka Creek tributary. Total concentration of cadmium exceeded the maximum contaminant level in one sample from the upstream site and in three samples from the downstream site.

Chromium: Dissolved, suspended, and total concentrations of chromium did not exceed the maximum contaminant level at any of the sites.

Lead: The maximum contaminant level of lead was exceeded in all phases at all sites. The average concentration for dissolved lead at the downstream site was $23 \mu \mathrm{g} / \mathrm{L}$ whereas the average at the upstream site was $9 \mu \mathrm{g} / \mathrm{L}$. The concentration of suspended lead increased about four-fold from the upstream to downstream site where the average was $44 \mu \mathrm{g} / \mathrm{L}$.

Mercury: Dissolved mercury exceeded the maximum contaminant level at both upstream and downstream sites. Suspended mercury exceeded the maximum level in one sample at the upstream site but none exceeded the maximum level at the downstream site. Dissolved, suspended, and total mercury concentrations did not exceed the maximum level in any of the samples from Taloka Creek tributary.

Iron: The average dissolved-iron concentrations were $160 \mu \mathrm{g} / \mathrm{L}$ at the upstream site, $48 \mu \mathrm{g} / \mathrm{L}$ at Taloka Creek tributary, and $89 \mu \mathrm{g} / \mathrm{L}$ at the downstream site, thus decreasing downstream. Conversely, average suspended iron concentrations were $970 \mu \mathrm{g} / \mathrm{L}$ at the upstream site, $1,424 \mu \mathrm{g} / \mathrm{L}$ at Taloka Creek tributary, and 2,484 $\mu \mathrm{g} / \mathrm{L}$ at the downstream site.

Aluminum and Manganese: The average dissolved aluminum and dissolved and suspended manganese were about two times greater at the downstream site than at the upstream site. The average suspended aluminum concentration was about four times greater at the downstream site than at the upstream site.

Metals in stream-bed materials: Of the toxic metals in stream-bed materials, onty lead appears to increase downstream. Arsenic, cadmium, chromium, and mercury did not show any significant differences between the upstream and downstream sites. The data for iron, aluminum, and manganese were too variable to draw any meaningful conclusions.

The excessive levels of toxic metals in water from Taloka Creek tributary and Taloka Creek at the downstream site can be attributed, in part, to mine drainage. However, the source or sources of the excessive concentrations, of cadmium, lead, and mercury in some of the samples from the upstream site is not known. Concentrations of toxic metals did not exceed the established levels in any of the sample collected since mining ceased in October, 1980 (tables 8 and 9 ). 


\section{Suitability of Taloka Creek Water}

The only use made of water in Taloka Creek is for livestock. Although the concentration of dissolved solids increases significantly downstream, the concentration is still within the recommended limit for livestock water (National Academy of Sciences and National Academy of Engineering, 1973). However, mercury and lead at times exceeded the recommended limits for livestock water at both the upstream and downstream sites.

Because of the excessive concentrations of lead and mercury, water in Taloka Creek was not suitable for human consumption. Taloka Creek flows into the Canadian River about $10 \mathrm{mi}$ downstream from the downstream station; the Canadian River flows into Robert $S$. Kerr Reservoir on the Arkansas River. Average flow of the Canadian River is about $5,000 \mathrm{ft}^{3} / \mathrm{s}$, thus the impact of mineralized water from Taloka Creek on the Canadian River probably is not measurable. 


\section{SUSPENDED SEDIMENT}

The quantity and characteristics of suspended sediment transported by Taloka Creek are affected by several interrelated environmental conditions. Major conditions include quantity and intensity of precipitation, land use and cover conditions, length and degree of slope, and soil characteristics. Because much of the precipitation occurs as thunderstorms of varying intensity during spring and summer months, the largest sediment loads can be expected at those times.

Major soil associations in most of the area are the Linker-Naldo and the Stigler-Counts-Tamaha; both associations are primarily loamy soils (Brinlee, 1975). The Linker-Naldo association is derived from sandstone and the Stigler-Counts-Tamaha is derived from shale. Both associations occur on upland slopes and broad crests where slopes generally are less than 5 percent. Grasses are the dominant vegetation.

Suspended-sediment samples from Taloka Creek (tables 11-13) represent conditions at the times thay were collected. Samples were collected irrespective of stream stage, either rising or falling, and do not necessarily correspond to peak discharge. Samples were collected with depth-integrating samplers, usually representing several verticals in the cross section. Each vertically sampled zone extended from the water surface to about $0.3 \mathrm{ft}$ above the stream bed, a limit established by sampler configuration. Suspended-sediment concentration is the velocity weighted concentration of sediment in the sampled zone expressed as milligrams of dry sediment per liter of water-sediment mixture.

The relationship between stream discharge and suspended sediment discharge is shown in figure 3. The data for Taloka Creek near Stigler shows the best relationship, however, only two data points are available for stream discharges greater than $50 \mathrm{ft} 3 / \mathrm{s}$. The relationship between stream discharge and suspended sediment discharge for Taloka Creek at Stigler and Taloka Creek tributary is not well defined for the expected rate of flow, partly because of lack of data. Some of the scatter of the points on the graph is attributed to using data from samples collected during both rising and falling stages. Under such conditions, the scatter is not unrealistic because rising-stage discharge would be expected to transport significantly larger amounts of suspended sediment than would falling-stage discharge.

Particle-size determinations separate the sediment into two size groups-diameters larger or smaller than $0.062 \mathrm{~mm}$ (millimeter). Particles with diameters larger than $0.062 \mathrm{~mm}$ are classed as sand; particles with diameters smaller than $0.062 \mathrm{~mm}$ are classed as silt-clay. As expected in an area where the bedrock is predominantly shale and the soil is mostly loam, the median for the silt-clay fraction ranged from 88 to 98 percent (table 14 ).

\section{STREAM-BED MATERIALS}

Samples of stream-bed material were analyzed for selected trace constituents and nutrients (table 15). The number of sampling points within a cross section or reach depended on the width of flow when the samples were collected. The values represent only the measured range of stream discharge. 

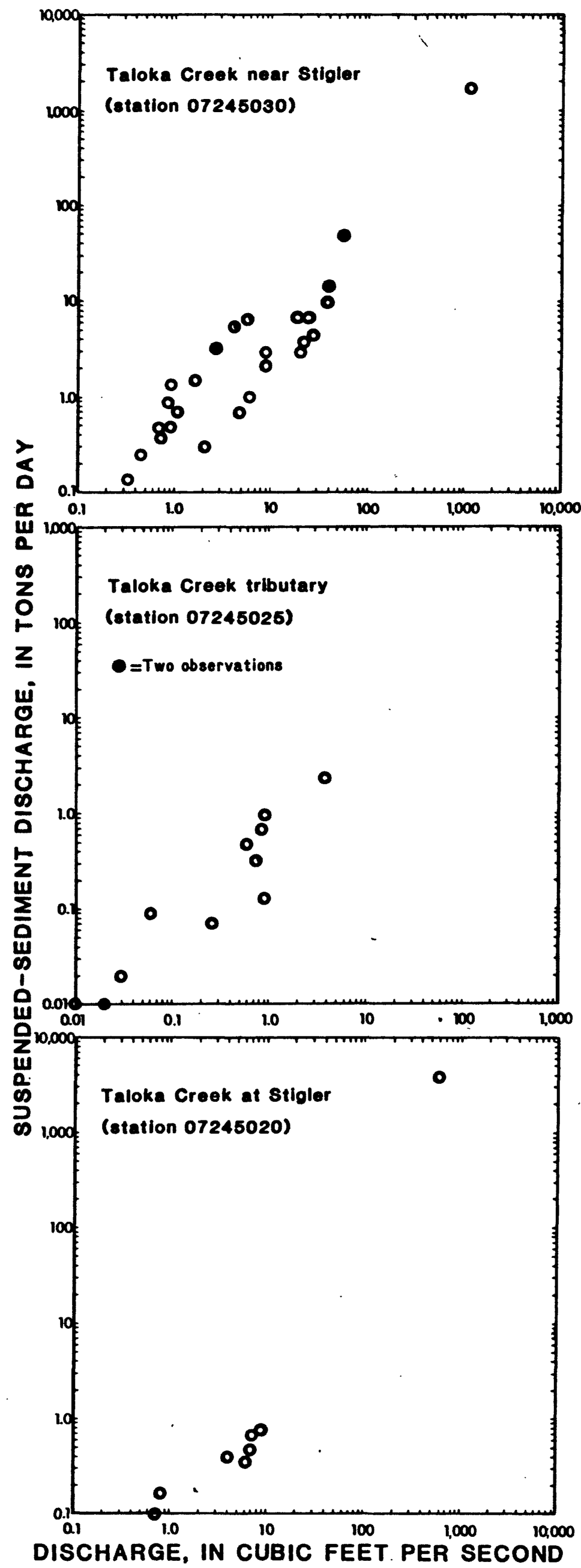

Figure 3. - Relationship between stream discharge and suspended-sediment discharge. 


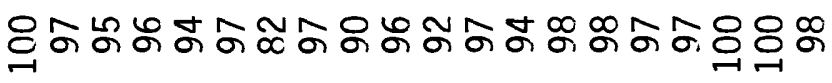

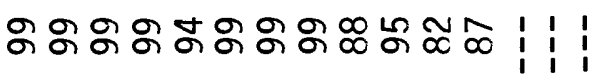

近

|

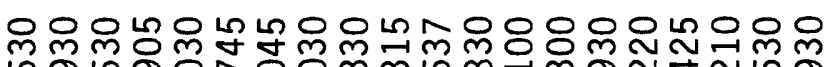

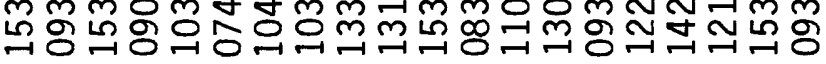

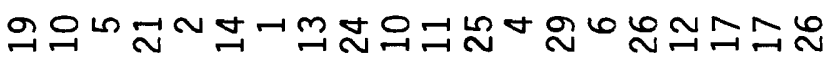

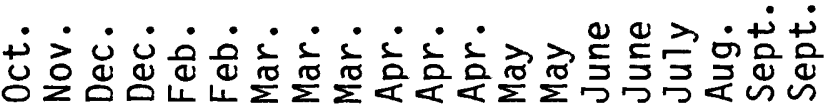

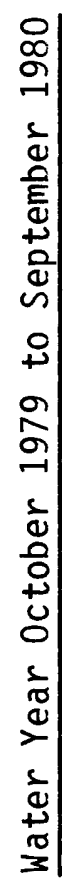

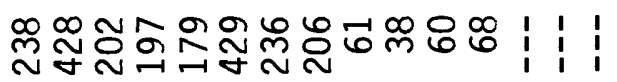

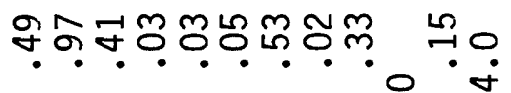
$\dot{*}$ i i i

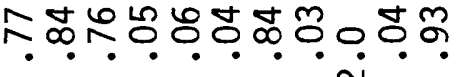
$\approx 000$

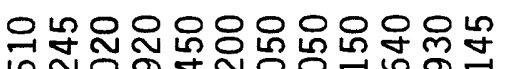

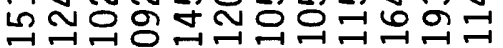

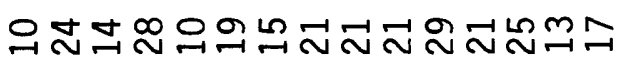

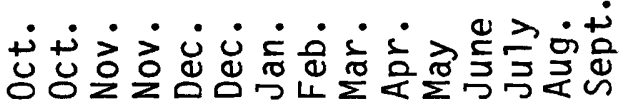




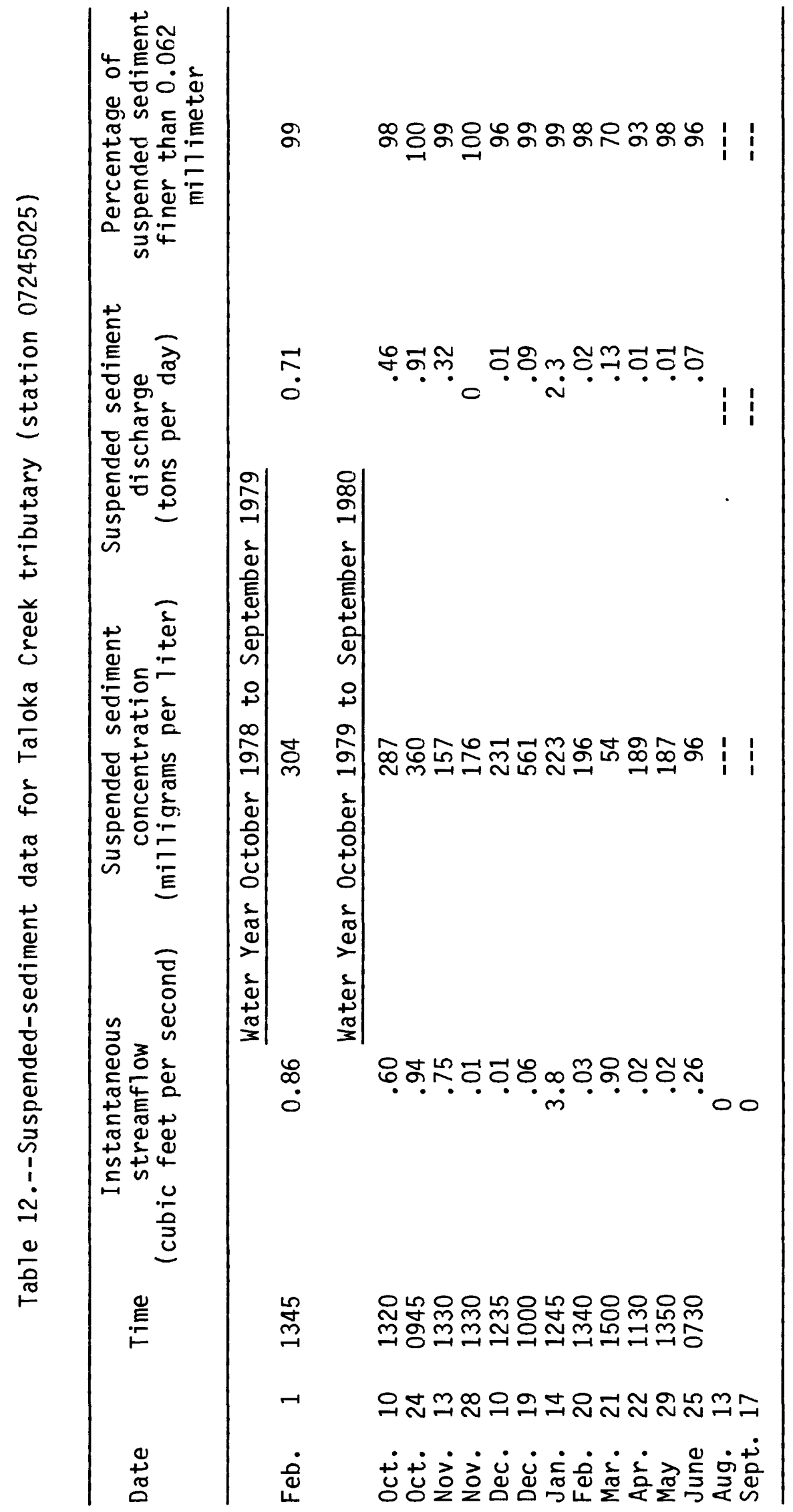




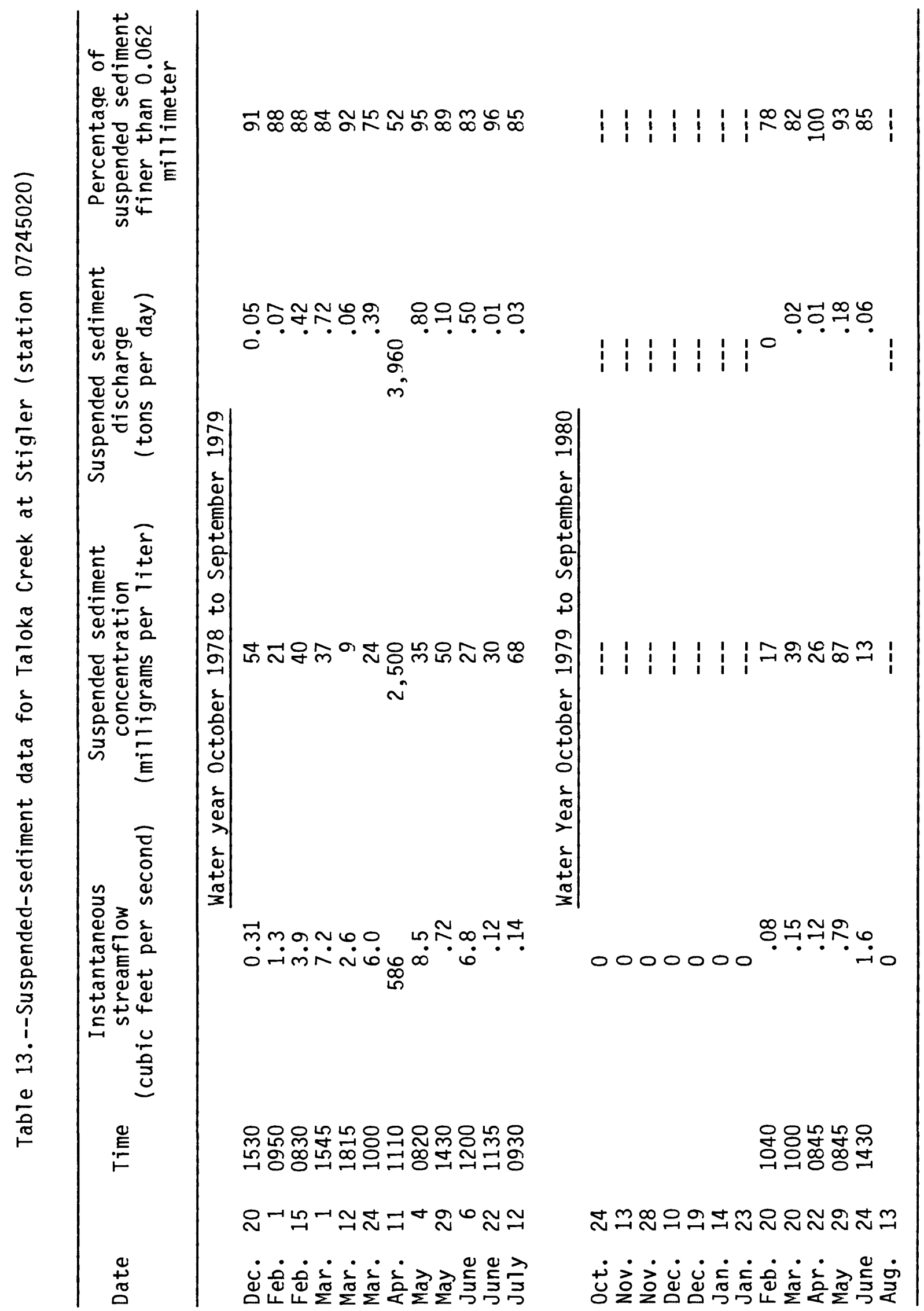




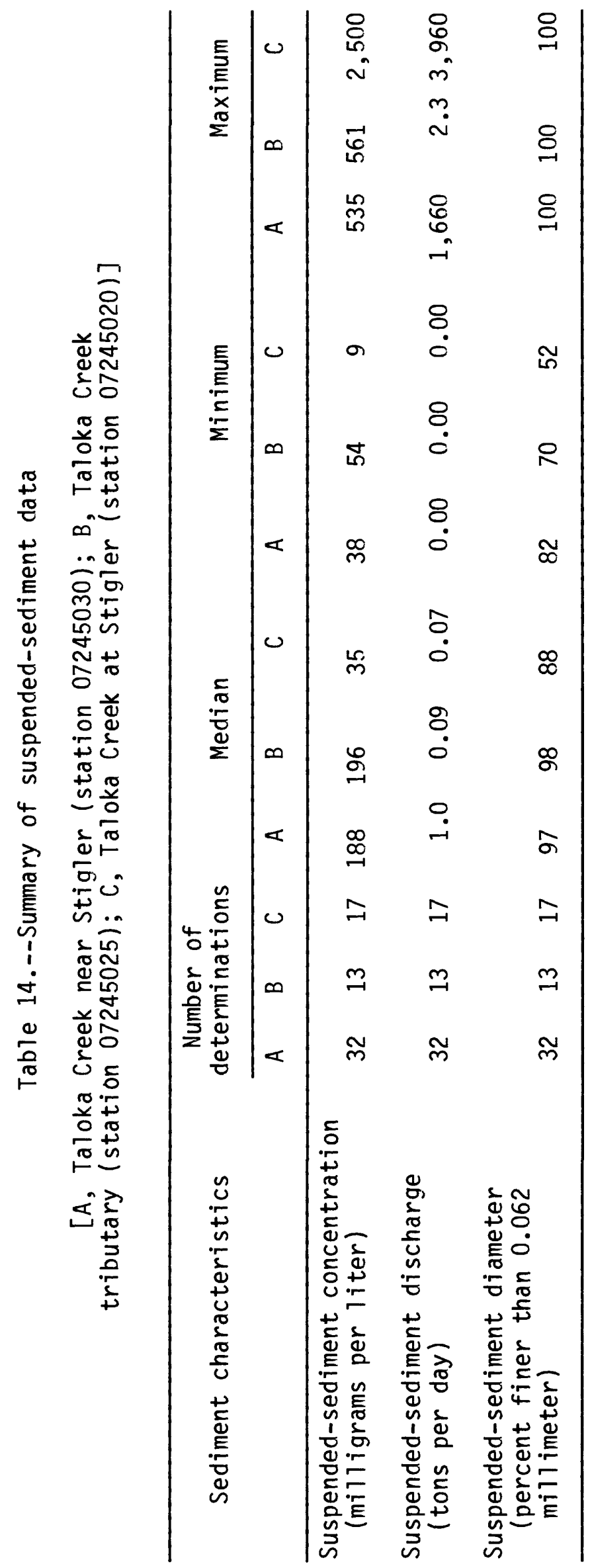



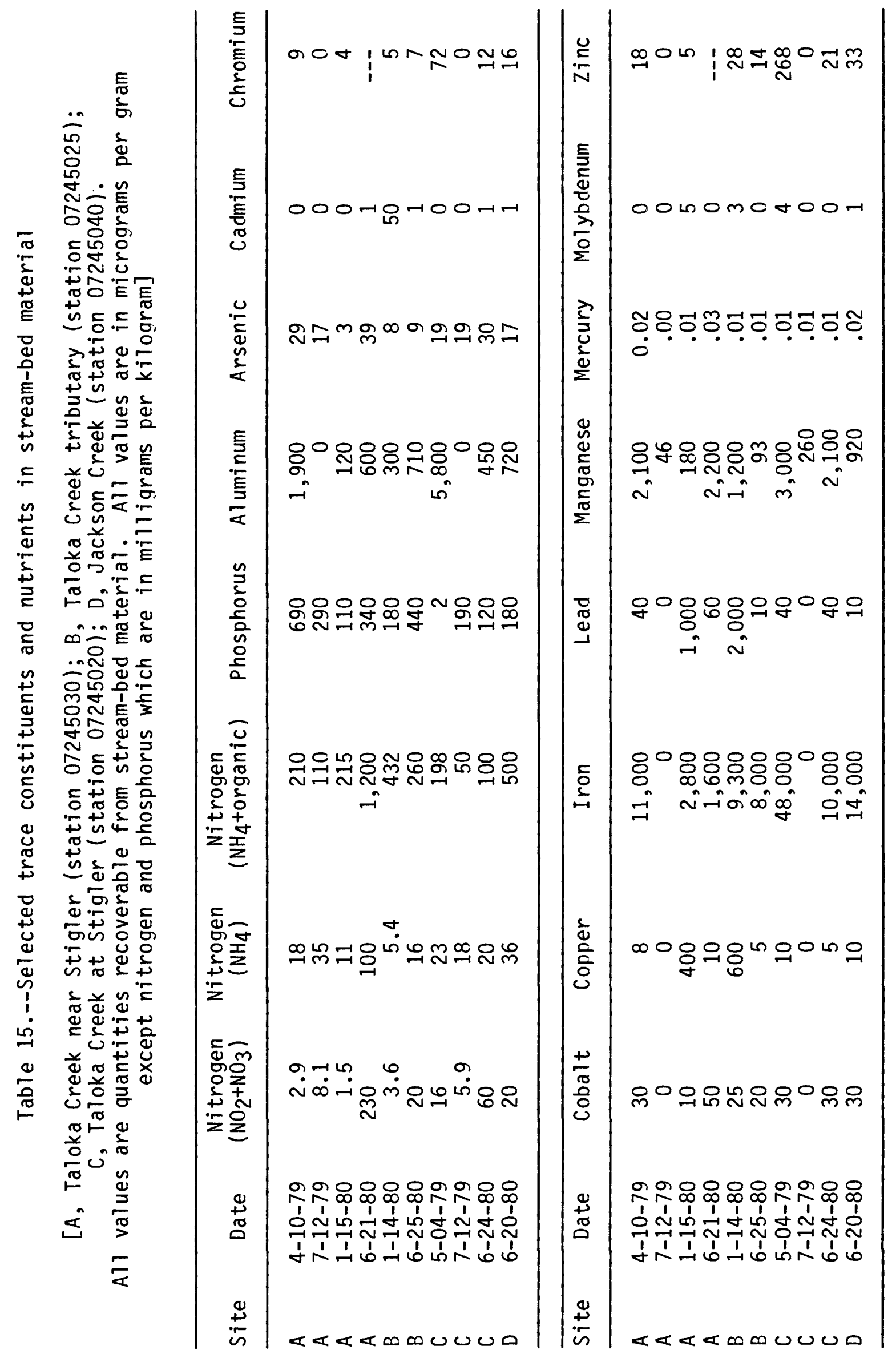


\section{WATER DEVELOPMENT AND USE}

Because of the limited availability and the variable quality of ground water, the town of Stigler as well as most of the surrounding area is supplied by a rural water district (0klahoma Water Resources Board, 1980) which obtains water from Lake Eufaula. Possibly as many as 60 wells supply water for domestic and livestock use; total ground water use probably is only a few thousand gallons per day. Additional development of ground water is not likely because of the ready availability of water from the rural system.

Streams in the area are used only to water livestock. Because the streams are dry during parts of most years, ponds have been constructed to supply stock water. The volume of water used for stock watering is estimated at 5,000 gal/d. Taloka and Jackson Creeks provide only limited habitat for wildlife and neither support fish of interest to sportsmen. 


\section{HYDROLOGIC EFFECTS OF SURFACE MINING}

Surface mining for coal and subsequent reclamation in the 0klahoma coal field may cause changes in the hydrologic system; these changes may be either short or long term. The following description of the coal-mining process as practiced in 0k1ahoma is summarized from Johnson (1974) to show how some of these changes may occur.

A surface-mining operation (fig. 4) involves digging a trench to expose the coal bed which is then removed. As each succeeding cut is made, the overburden or spoil is placed into the cut previously excavated. Successive cuts are mined until the overburden thickness becomes so great that the coal can no longer be mined profitably. The final cut leaves an open trench bounded by the last spoil pile on one side and the undisturbed highwall on the other. The ridges of spoil are graded to a rolling topography and revegetated with pasture grasses. The final cut and other depressions partly fill with water from precipitation and ground-water seepage. The revegetated area usually is not grazed until the grass has become well established.

A readily apparent change in the hydrologic system resulting from surface mining is the creation of additional water storage in the last mine cut shown in figure 4 . A mine pond $0.5 \mathrm{mi}$ long, $200 \mathrm{ft}$ wide, and containing 30 $\mathrm{ft}$ of water has a volume of about 360 acre-ft, a valuable asset in an area where groundwater is limited. Such a pond would provide habitat for aquatic and semiaquatic wildiife and could be stocked with fish as has been done in other parts of the coal field. Also, water from mine ponds may be used for stock, domestic, municipal, and irrigation supply if the quality is suitable.

In addition to increasing the storage of water in mine ponds, other changes in the hydrologic system may include (1) changes in permeability and ground water storage, (2) changes in runoff and streamflow characteristics, (3) changes in drainage patterns, (4) changes in the chemical quality of water, and (5) changes in the sediment loads of streams.

\section{Changes in permeability and ground-water storage}

overburden in the southern part of the Oklahoma coal field consists mainly of shale with some siltstone and sandstone; these rocks have minimal porosity and permeability. During mining, however, the overburden is broken and shattered to form spoil with many openings that may facilitate the entry, movement, and storage of water. Water stored in the spoil may (a) move into adjacent bedrock, (b) be slowly discharged to streams, and (c) be used by plants.

The volume of water entering the spoil is partly controlled by the permeability of the surface and near-surface material. Where that material consists of silt and clay, openings in the spoil may be plugged preventing or limiting the volume and rate of infiltration. For example, a test hole (10N-21E-33 CCC 1), located about $10 \mathrm{ft}$ from a small pond and at the same altitude, was augered to a depth of $37.5 \mathrm{ft}$ in partly reclaimed spoil of broken shale with some blocks of sandstone. The upper $11 \mathrm{ft}$ of spoil was moist but below that depth it was completely dry thus the bottom of the pond at this locality must be sealed with fine sediment thereby limiting downward movement of water. 0ther larger and deeper depressions nearby did not contain ponds indicating that the surface material in these depressions is permeable. 

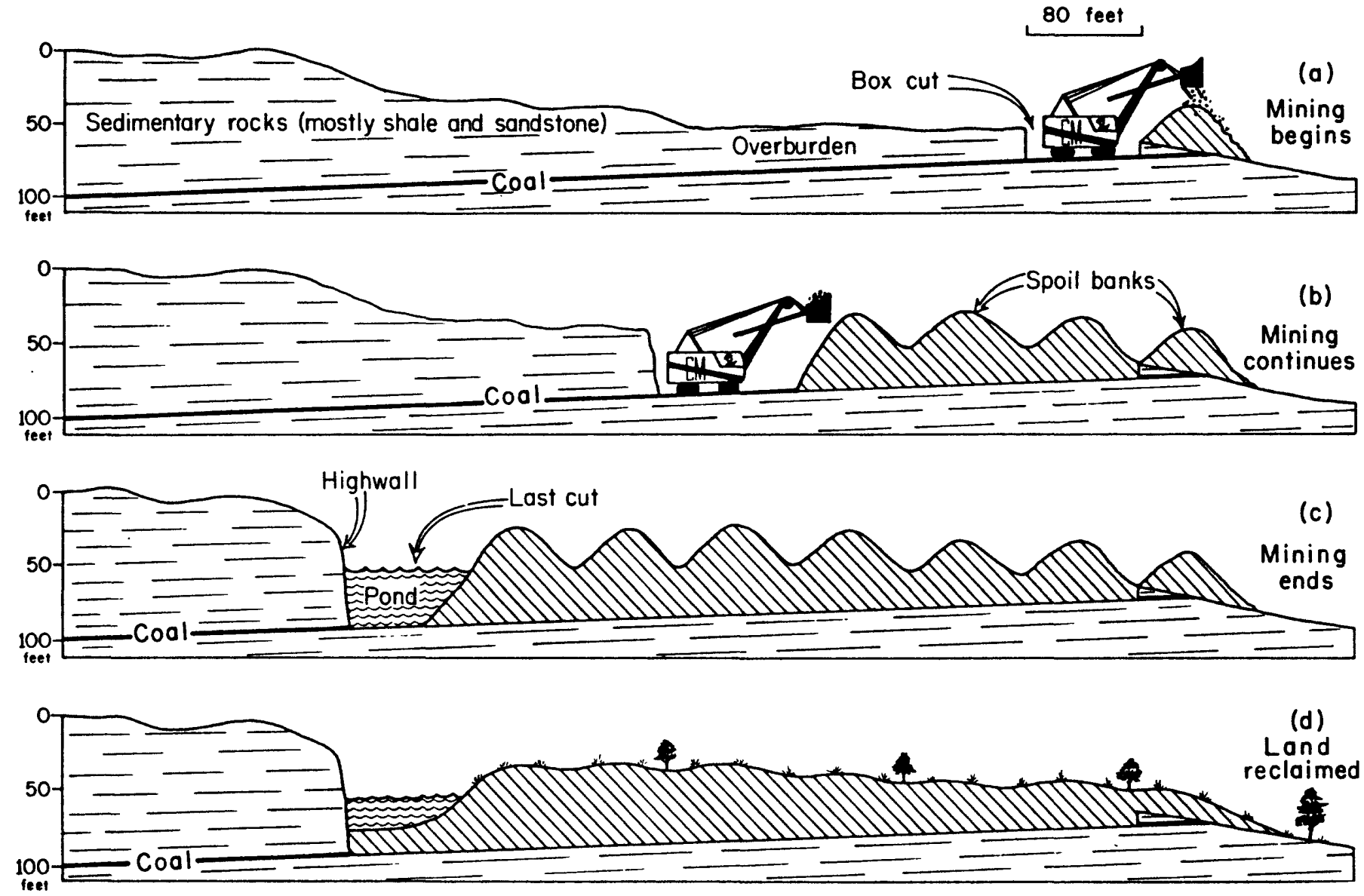

Figure 4. - Schematic cross section showing stages of surface mining for coal (from Johnson, 1974). 
2. Changes in runoff and streamflow characteristics

Observations in various parts of the Oklahoma coal field show that if appropriate reclamation procedures are used and climatic conditions are favorable, grasses on reclaimed spoil may be more lush and have denser growth than the original native vegetation. This denser plant growth tends to retard overland storm runoff so that it has more time to soak into the soil and, as a consequence, less water reaches streams during times of normally high runoff. Conversely, water stored in the spoil, under some circumstances, may be slowly released to streams thereby sustaining streamflow during dry periods. The overall resulting change in streamflow would be to decrease peak discharges and to extend periods of $10 \mathrm{w}$ flow.

Streamflow characteristics also may be affected by interception of runoff in mine ponds and depressions left in the reclaimed areas. In the Stigler area, drainageways in parts of secs. 4, 5, and 33, T. 9 N., R. 21 E. have been disrupted by mining and reclamation so that some of the overland flow is intercepted before it can reach Taloka Creek; about $1 \mathrm{mi}^{2}$ or about 5 percent of the basin now has interior drainage and is noncontributing.

Much of the old spoil in the Stigler area has been partly reclaimed by grading to a rolling topography and seeding with grass but the topsoil was not replaced. This partly reclaimed area is vegetated with weeds, wildflowers, patches of grass, and naturally seeded trees -- cottonwood, sycamore, willow, and black locust -- 10-30 ft tall. Recently mined areas have been reclaimed by grading, replacing the topsoil, and seeding with grass. Although rainfall was deficient much of the time since this reclamation was completed, the recently-mined area appears to be better or at least as well vegetated as nearby natural pastures.

The discharge characteristics of Taloka Creek probably have been changed to some extent by mining and subsequent reclamation as described above. However, the data available are not adequate to evaluate these changes.

3. Changes in drainage patterns

To prevent storm runoff from entering surface pits during mining operations, some diversions of stream channels may be necessary. These diversions generally are of limited extent and, if appropriately constructed and maintained, are not likely to have any great effect on the hydrologic system. Mining across drainageways may cause permanent changes as described in the preceding section. The significance of these changes would largely depend on the size of the area thus disrupted.

4. Changes in chemical quality of water

Minerals in the overburden and coal are in equilibrium with their environment as long as that environment is not changed. Mining, however, disturbs that equilibrium and the minerals react with various chemical components of their new environment such as water, oxygen, and plant acids. For example, pyrite, which is commonly associated with coal, reacts with water and oxygen to release iron and sulfate and to increase the acidity of the water. Other chemical reactions may result in the release of various trace elements, such as lead, copper, and zinc that may be present in the coal. As a consequence of these reactions, new and generally undesirable chemicals may be added to the hydrologic system.

No data are available to determine the effect, if any, of mining on the chemical quality of ground water in the Stigler area. Adverse changes in the chemical quality of surface water has been described in the preceeding pages; how long these changes will persists is unknown. However, as the various 
minerals, such as pyrite and aypsum, come into equilibrium with their new environment and are leached from the spoil, the dissolved minerals being added to the streams can be expected to diminish.

5. Changes in sediment loads

Disruption of the land surface during mining and before the spoil is fully reclaimed will increase the quantity of sediment available to streams. However, if appropriate mining practices are followed, such as the use of settling ponds, the quantity of sediment added to streams can be decreased. Likewise, the time available for addition of the sediment can be decreased if the spoil is revegetated rapidly and effectively. Although mining in the Stigler area may have increased the sediment load of Taloka Creek at least temporarily, the data available are not adequate to evaluate the quantity or duration of such increase.

\section{SUMMARY}

The water resources of the Stigler area are limited. Wells in parts of the area yield enough water for domestic or stock supplies but larger yields are not available due to the minimal permeability of the rocks. Water for much of the area is supplied by a rural water district. Streams in the area commoniy are dry about 3 months of the year and, therefore, they are not a dependable source of water and provide only limited habitat for wild life. Ponds are relied on to supply water for livestock.

The chemical quality of ground water is extremely variable; the causes of these variations are unknown but the water generally is suitable for domestic use. Surface mining for coal has had an adverse effect on the chemical quality of water in Taloka Creek; how long these effects will persist is unknown. The effects of surface mining on the sediment load of Taloka Creek cannot be determined with the available data. However, the mined area has been mostly reclaimed and revegetated so that the sediment load should decrease with time. 


\section{SELECTED REFERENCES}

Brinlee, R. C., 1975, Soil survey of Haskell County, Ok1ahoma: U.S. Department of Agrigulture, Soil Conservation Service, $78 \mathrm{p}$.

Holbrook, Stanley, 1975, Climate in Soil survey of Haskel1 County, Ok1ahoma: U.S. Department of Agriculture, Soil Conservation Service, p. 73.

Johnson, K. S., 1974, Maps and description of disturbed and reclaimed surface-mined coal lands in eastern 0k1ahoma: Oklahoma Geological Survey Map GM-17, 3 sheets, scale 1:125,000.

Johnson, K. S., Branson, C. C., Curtis, N. M., Jr., Ham, H. E., Marcher, M. V., and Roberts, J. F., 1972, Geology and Earth resources of Ok lahoma: Oklahoma Geological Survey Educational Publication 1, 8 p.

Johnson, K. S., Kidd, C. M., and Butler, R. C., 1981, Bibliography of abandoned coal-mine lands in 0klahoma: Oklahoma Geological Survey Special Publication 81-2, 84 p.

Marcher, M. V., 1969, Reconnaissance of the water resources of the Fort Smith quadrangle, east-central 0k1ahoma: Oklahoma Geological Survey Hydrologic Atlas 1,4 sheets, scale 1:250,000.

Marcher, M. V., Bergman, D. L., Stoner, J. D., and B1umer, S. P., 1982, Preliminary apprasial of the hydrology of the Blocker area, Pittsburg County, OK1ahoma: U.S. Geological Survey Water-Resources Investigations Open-File Report 81-1187, 48 p.

National Academy of Sciences and National Academy of Engineering, 1973 (1974), Water quality criteria, 1972: U.S. Government Printing Office, $594 \mathrm{p}$.

Oakes, M. C., and Knechtel, M. M., 1948, Geology and mineral resources of Haske11 County, OK1ahoma: Ok1ahoma Geological Survey Bulletin 67, $134 \mathrm{p}$.

0k1ahoma Water Resources Board, 1970, Appraisal of the water and related 1 and resources of $0 k 1$ ahoma, Region Seven: OKlahoma Water Resources Board, $141 \mathrm{p}$.

0k1ahoma Water Resources Board, 1980, Rural water systems in Oklahoma: Oklahoma Water Resources Board Publication 98, 160 p.

Sauer, V. B., 1974, Flood characteristics of Oklahoma streams: U.S. Geological Survey Water-Resources Investigations 52-73, $301 \mathrm{p}$.

Thomas, W. 0., Jr., 1976, Techniques for estimating flood depths for Oklahoma streams: U.S. Geological Survey Water-Resources Investigations 2-76, $38 \mathrm{p}$.

Thomas, W. 0., Jr., and Corley, R. K., 1977, Techniques for estimating flood discharges for OKlahoma streams: U.S. Geological Survey Water-Resources Investigations $77-54,170 \mathrm{p}$.

U.S. Environmental Protection Agency, 1976, National interim primary drinking water regulations: U.S. Environmental Protection Agency EPA-570/9-76$003,159 \mathrm{p}$. 


\begin{tabular}{|c|c|c|}
\hline Inch-pound & Multiply by & To obtain SI units \\
\hline foot $(f t)$ & 0.3048 & meter \\
\hline inch (in) & 25.4 & millimeter \\
\hline square mile (sq mi) & 2.590 & square kilometer \\
\hline acre-foot (acre-ft) & 1,233 & cubic meter \\
\hline $\begin{array}{l}\text { cubic foot per second } \\
\qquad\left(\mathrm{ft}^{3} / \mathrm{s}\right)\end{array}$ & 0.02832 & $\begin{array}{l}\text { cubic meter per } \\
\text { second) }\end{array}$ \\
\hline foot per mile $(\mathrm{ft} / \mathrm{mi})$ & 0.1894 & meter per kilometer \\
\hline ton per day (ton/d) & 0.9072 & megagram per day \\
\hline $\begin{array}{l}\text { gallon per minute } \\
\text { (gal/min) }\end{array}$ & 0.06309 & liter per second \\
\hline $\begin{array}{l}\text { gallon per day (gal/d) } \\
\text { mile (mi) }\end{array}$ & $\begin{array}{l}0.003785 \\
1.609\end{array}$ & $\begin{array}{l}\text { cubic meter per day } \\
\text { kilometer }\end{array}$ \\
\hline $\begin{array}{l}\text { micromho per centimeter } \\
\text { at } 25^{\circ} \text { Celsius ( } \mu \text { mho) }\end{array}$ & 1.0 & $\begin{array}{l}\text { microsiemens per } \\
\text { centimeter at } 25^{\circ} \\
\text { Celsius }\end{array}$ \\
\hline
\end{tabular}

